\title{
Global Disappearance of Tropical Mountain Glaciers: Observations, Causes, and Challenges
}

\author{
Bijeesh Kozhikkodan Veettil ${ }^{1,2, * \mathbb{B}}$ and Ulrich Kamp ${ }^{3}$ \\ 1 Department for Management of Science and Technology Development, Ton Duc Thang University, \\ Ho Chi Minh City 700000, Vietnam \\ 2 Faculty of Environment and Labour Safety, Ton Duc Thang University, Ho Chi Minh City 700000, Vietnam \\ 3 Department of Natural Sciences, University of Michigan-Dearborn, Dearborn, MI 48128, USA; \\ ukamp@umich.edu \\ * Correspondence: bijeesh.veettil@tdtu.edu.vn
}

Received: 12 February 2019; Accepted: 26 April 2019; Published: 30 April 2019

check for updates

\begin{abstract}
This article reviews the current status of tropical glaciers in the South American Andes, East Africa, and Australasia by shedding light on past, present, and future glacier coverage in the tropics, the influence of global and regional climates on the tropical glaciers, the regional importance of these glaciers, and challenges of ongoing glacier recessions. While tropical glaciers have predominantly receded since the Little Ice Age, the rate of shrinkage has accelerated since the late 1970s as a result of climate changes. As a result, socio-ecological implications occur around ecosystem health, natural hazards, freshwater resources, agriculture, hydropower, mining, human and animal health, traditions and spirituality, and peace.
\end{abstract}

Keywords: tropical glaciers; climate change; glacier extinction; water resources; adaptation strategies

\section{Introduction}

Mountain glaciers, particularly in the tropics, are currently diminishing rapidly and are considered as good indicators of climate change [1], owing to their relatively fast response time toward perturbations in climate variables such as precipitation, air temperature, and atmospheric humidity [2]. Many tropical glaciers, such as those in Peru and Bolivia, are critical buffers against reduced precipitation during the dry season [3]. During the initial stages, enhanced glacier shrinkage in tropical mountains may provoke glacier-related hazards such as glacial lake outburst floods (GLOF) [4]. Hydroelectric power plants in Peru [5] and Bolivia [6] often depend on glacier-fed rivers. Many glacierized tropical mountain regions are also important in tourism, for example, in the form of ski resorts. In this context, a timely assessment of tropical glaciers is important.

While numerous review articles $[2,3,7,8]$ and research papers are available on tropical Andean glaciers, much less attention is given to tropical glaciers in Africa and Asia, partly owing to small ice coverage. Whilst tropical glaciers in the Cordillera Blanca have been studied extensively, limited studies on glacier fluctuations and the influence of climate change on the cryosphere are available from East Africa [9-15] and Australasia [16-19]. A few recent studies using remote sensing data exist on glaciers in Australasia [20-22].

In this review article, we present a picture of the glacier distribution across the tropics, the influence of global and regional climates on the tropical glaciers, and their regional importance. Further, we discuss the possible impacts and challenges of continuing loss of glacier coverage throughout the tropics. For a few glaciers (Mt Kenya, Kenya; Cordillera Tres Cruces, Bolivia), we estimated glacier area changes using Landsat satellite image series and the normalized difference snow index (NDSI) method [20,22]. 


\section{Glaciers in the Tropics}

Tropical glaciers are found between the Tropic of Cancer and the Tropic of Capricorn $\left(23^{\circ} 26^{\prime} 13.3^{\prime \prime} \mathrm{N}\right.$; $23^{\circ} 26^{\prime} 13.3^{\prime \prime}$ S) within the Intertropical Convergence Zone (ITCZ), and wherever the diurnal temperature range equals the annual temperature range (i.e., $\Delta \mathrm{T}_{\mathrm{d}}=\Delta \mathrm{T}_{\mathrm{a}}$ ) [1]. Tropical glaciers exist in the South American Andes, East Africa, and Australasia (Figure 1). The recent Randolph Glacier Inventory (RGI; version 5.0) estimates the total area of tropical glaciers at $2344.15 \mathrm{~km}^{2}$ (Table 1).

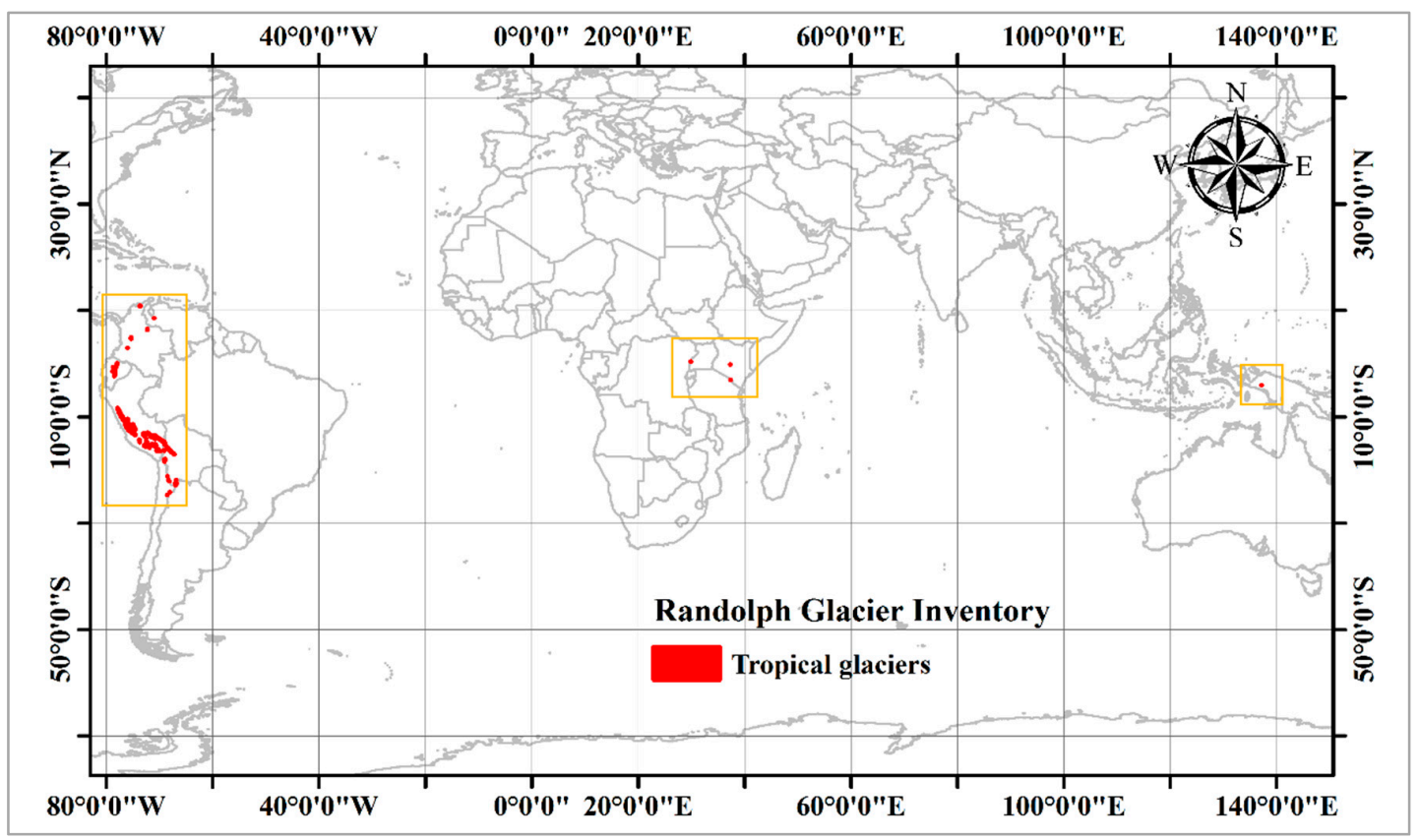

Figure 1. Distribution of tropical glaciers globally.

Table 1. Tropical glacier areas by region and country using data from the Randolph Glacier Inventory.

\begin{tabular}{llr}
\hline Region & Country & Area $\mathbf{( k m}^{\mathbf{2}} \mathbf{~}$ \\
\hline & Venezuela & 0.79 \\
& Colombia & 66.19 \\
& Ecuador & 123.9 \\
South America & Peru & 1602.96 \\
& Bolivia & 531.58 \\
& Northern Chile & 11.81 \\
& Northern Argentina & 0.32 \\
& Total & 2337.55 \\
\hline \multirow{4}{*}{ Africa } & Kenya & 0.40 \\
& Tanzania & 2.87 \\
Irian Jaya & Uganda-Democratic Republic of Congo & 1.14 \\
& Total & 4.41 \\
Entire Tropics & Indonesia & 2.14 \\
\hline
\end{tabular}

\subsection{Tropical Andes}

More than $99 \%$ of tropical glaciers are situated in the Andes of South America, including Venezuela, Colombia, Ecuador, Peru, Bolivia, Chile, and Argentina. Much of the previous research has been undertaken using remotely sensed data, as the difficult terrain presents challenges in carrying out extensive fieldwork.

The glaciated areas in Venezuela, Colombia, and Ecuador belong to the inner tropics, with a year-round precipitation pattern that lacks any seasonality. In Venezuela, the Humboldt Glacier in the 
Cordillera Mérida, an extension of the Cordillera Oriental in Colombia, is the only remaining glacier in the country. In Colombia, glaciers exist in the Sierra Nevada de Santa Marta, which is detached from the Cordillera Central, in the Cordillera Central (Nevado del Ruiz, Nevado de Santa Isabel, Nevado del Tolima, and Nevado del Huila), and in the Cordillera Oriental (Sierra Nevada del Cocuy). Glaciers in Ecuador occur in the Cordillera Occidental in the west towards the Pacific, and in the Cordillera Oriental in the east towards the Amazon Basin. Glaciers in the drier Cordillera Occidental are restricted to Carihuairazo, Chimborazo, and Iliniza, whereas the higher precipitation arriving from the Amazon Basin in the Cordillera Oriental allows for a much larger glaciation, for example, at Antisana, Cayambe, Altar, Cotopaxi, and Sangay. The glaciers at Antisana contribute to the water supply of the capital, Quito [23].

Glaciers in Peru, Bolivia, northern Chile, and northern Argentina belong to the outer tropics, where seasonality in precipitation is noticeable. Glaciated peaks in Peru are distributed among the major cordilleras Occidental, Central, and Oriental. Within these three, 20 smaller glaciated cordilleras exist, including Apolobamba, Blanca, Huallanca, and La Raya [24]. The Cordillera Blanca is the most extensively glaciated region in Peru. In Bolivia, glaciers are located in the cordilleras Apolobamba, Real, and Tres Cruces, together with Nevado Santa Vera Cruz of the Cordillera Oriental, whereas the major glacier coverage in the Cordillera Occidental is limited to three ice-covered volcanoes at the border to Chile (Nevado Sajama, Volcán Parinacota, and Pomerape). Glaciers in the Dry Andes (between $17^{\circ} 30^{\prime} \mathrm{S}$ and $35^{\circ} \mathrm{S}$ ) of northern Chile and Argentina are situated on active or dormant stratovolcanoes.

\subsection{East Africa}

Currently, on the African continent, glaciers are limited to two volcanoes-Mt Kenya in Kenya and Mt Kilimanjaro in Tanzania-and the Ruwenzori mountain group on the border between Uganda and the Democratic Republic of Congo. As per the latest RGI data, an area of more than $4 \mathrm{~km}^{2}$ is still glaciated in Africa. The climate in these glaciated locations is typical of the inner tropics; that is, precipitation occurs all year round with two maxima, from March to May and from September to October.

Mt Kilimanjaro (5895 m) is the highest mountain on the African continent, and a dormant volcano that was extensively glaciated only in the 1990s, when 12 glaciers still existed [25]; however, most of them disappeared in the early 21st century [12-14]. The glaciated stratovolcano Mt Kenya (5199 m) is the second highest mountain in Africa. The first expedition to the summit of Mt Kenya was in the late 19th century, and since then, Lewis Glacier, one of the glaciers found on the mountain, has been extensively studied [25]. The Ruwenzori Mountains are also known as the 'Mountains of the Moon' or Luane Montes, named by Greek philosophers such as Aristotle; it is also one of the sources of the Nile. The highest peaks, Mt Stanley (5109 m), Mt Speke (4891 m), and Mt Baker (4873 m), are still glaciated.

\subsection{Australasia}

Tropical glaciers in Australasia can be found on the highest summits of Puncak Jaya in the Indonesian province of Papua (formerly Irian Jaja) and include East Northwall Firn (4862 m), Carstensz Glacier (4844 m), and West Northwall Firn (4750 m). The region has a typical inner tropics climate, and glaciers are highly sensitive to variations in air temperature. The mass balance of the Puncak Jaya glaciers has been continuously negative since the early 20th century [17].

\section{Causes of Glacier Recession}

Tropical glaciers reached their Little Ice Age (LIA) maximum extent in the 19th century and have been retreating since then [20]. Tropical glaciers are widely considered as indicators of global and regional climate change [1], owing to their high sensitivity to perturbations in climate and relatively fast response time [3]. Global climate change impacts on tropical glaciers may vary depending on the geographical region and its climate, as well as the topographic situation (elevation, aspect, and slope). Nevertheless, the Intergovernmental Panel on Climate Change (IPCC) $[26,27]$ mentioned its concern about the rapid recession of tropical glaciers under global warming scenarios. 
Numerous studies exist on the influence of El Niño-Southern Oscillation (ENSO) and Pacific Decadal Oscillation (PDO) on tropical glaciers in the Andes [23,28-34], but are less frequent for Australasia [21]. During El Niño events, a rise in air temperature and reduction in precipitation have been observed throughout the tropics [35-37]. Since the late 1970s, the frequency of El Niño and the occurrences of warm phases of PDO have been increasing [2,38], which coincides with the general rapid shrinkage of the tropical glaciers.

By the end of the 21st century, climate change-induced temperature increase is predicted to accelerate at higher elevations of the tropical landscape, resulting from humidity conditions and water vapor feedback in the upper troposphere $[39,40]$. In the tropical Andes, the temperature increase may reach up to $0.11^{\circ} \mathrm{C}$ per decade, almost double the predicted global increase of $0.06{ }^{\circ} \mathrm{C}$ [41]. This stronger warming at high altitudes results from snow albedo and surface-based feedbacks, water vapor changes and latent heat release, surface water vapor and radiative flux changes, surface heat loss and temperature change, aerosols, and elevation-dependent warming (EDW) at high altitude mountains [42]. Even though the interrelationships among those factors are not fully understood, a rise in air temperature at high elevation tropical mountains will result in glacier loss. Furthermore, the daily minimum temperature will increase faster than the maximum temperature, which could be explained with different atmospheric mechanisms during the day and the night [42]. When daily minimum temperatures increase faster than daily maximum temperatures, the diurnal temperature range will decrease, causing higher atmospheric water vapor contents, which in turn enhances glacier melting. Such an accelerated warming pattern at higher elevations has also been documented for the Peruvian Andes [43]. However, glacier response to climatic forcing is more complex in the tropics, because glacier recession in this region is likely to be related to other components of the energy balance (net radiation, latent, sensible, and ground heat fluxes) in thermally homogeneous areas [44].

Other regional and local natural and anthropogenic phenomena like volcanic eruptions and mining activities may also influence the pace of glacier retreat [45]. The presence of particulate matter such as volcanic dust or black carbon that deposits on the glacier surface reduces the ice's surface albedo, resulting in enhanced melting [46].

\section{Historical Observations of Glacier Extent}

Early observations of the glaciers in the Tropics range back to the 16th century. Initial studies were based on qualitative data such as maps and descriptions of sites, while more recently, quantitative data are increasingly being used.

\subsection{Tropical Andes}

Observations on the glaciers in Venezuela reach back to the second half of the 19th century, for example, at snow-covered stratovolcanoes such as the Volcano of Puracé, which are ice-free today, and continued into the early 20th century [47-52]. The first more detailed map displaying the distribution of glaciers in the Sierra Nevada de Mérida dates back to the 1920s [53].

Numerous older documents and reports ranging back to the mid-19th century describe the snowand glacier-covered mountains in Colombia [54-60]. Some studies mentioned that the snowline altitude during the last advance may have reached as low as $3000 \mathrm{~m}[58,61,62]$. We estimated a current lowest glacier limit of $4700 \mathrm{~m}$.

The snow-capped peaks in Ecuador and their importance as water resources have been mentioned in studies since the mid-19th century [63-68]. Antisana and Cayambe had a similar snow cover extent, and a number of nearby peaks such as Cerro Saraurcu $(4640 \mathrm{~m})$ were glaciated [64].

Glacier observations in Peru started in the early 16th century by members of the Hernando Pizarro expedition to the Cordillera Blanca [24], although a first scientific study of the glaciers was presented much later, in the 19th century [69]. In the early 20th century, expeditions and regional surveys delivered numerous glacier and glacial lake studies and presented, for example, several accurate glacier maps derived from extensive fieldwork and the interpretation of terrestrial photographs [62,70-79]. 
Peru's ice was classified into mountain glaciers $(91 \%)$, rock glaciers $(<9 \%)$, and Quelccaya ice cap-the second largest glaciated area in the tropics globally after Coropuna in southern Peru.

The first recorded glacier observations in Bolivia were carried out during d'Orbigny's expedition to South American countries between 1826 and 1833 [80]. In the early 20th century, studies and expedition notes focused mostly on the Cordillera Real [81-87].

In the early 20th century, studies on the glaciers in the Dry Andes of northern Chile and Argentina mentioned the influence of westerly winds and solar radiation exposure on glacier distribution-snow accumulated on eastern slopes, which were sheltered from wind [88,89]. Maps were generated by governmental agencies such as the Comisión de Limites and Carta Nacional de Chile.

\subsection{East Africa}

The glaciers of East Africa have received larger interest since the mid-19th century, resulting in numerous publications for Mt Kenya [90-95], Mt Kilimanjaro [95-98], and the Ruwenzori Mountains [95,99-105]. Nilsson (1931) [95] observed several glaciers at Mt Kenya, including Gregory Glacier and Lewis Glaciers, when carrying out height estimates, and he found moraines at an elevation of less than $3400 \mathrm{~m}$. Our mapping resulted in a current glacier coverage above $4750 \mathrm{~m}$. While there was a debate about the height of Mt Kilimanjaro, early explorers consistently reported about its glacier-covered summit since the mid-19th century [96]. Johnston (1885) [97] and Meyer (1890a, 1890b, 1891) [102-104] took photographs and generated the first maps of the mountain's snow-covered heights. Nilsson (1931) [95] compared his terrestrial photographs with those taken earlier by Klute (1920) [98] and Meyer (1890a, b, 1891, 1900) [102-105] and concluded that Kilimanjaro's glaciers were in recession. Glaciers in the Ruwenzori Mountains were first documented at the very beginning of the 20th century; 30 glaciers were identified and 20 were named in this region [100,101]. Abruzzi (1907) [101] produced a map at 1:50,000 scale of the peaks using photographs, even though some errors were later identified by Busk (1954) [106].

\subsection{Australasia}

Glaciers of Australasia are located mainly on the high altitude summits of Puncak Jaya, where they were first sighted by the Dutch explorer Jan Carstensz in 1623 [107]; the name 'Carstensz Pyramid' was given to Puncak Jaya afterwards. In 1909, another Dutch explorer, Hendrik Albert Lorentz, climbed Puncak Jaya and observed its glaciers [108].

\section{Remotely-Sensed Glacier Observations}

Glacier monitoring entered a new phase in the mid-20th century with the emergence of aerial photogrammetry in the early 1950s and satellite remote sensing in the 1970s [25].

\subsection{Tropical Andes}

Glaciers in South America have been experiencing an unprecedented retreat since the mid-20th century, particularly since the late 1970s, although the rate of shrinkage varies with geographical location and is influenced by global and regional climate forcing $[2,3,8]$. Detailed reviews on recent glacier changes in the tropical South America are available [2,8,109], but a brief overview is given here.

Glaciers of the inner tropics within Venezuela, Colombia, and Ecuador, where precipitation occurs throughout the year and temperature varies little throughout the year [110], showed an exceptionally high rate of shrinkage in recent decades [111-114]. The glacier area in Venezuela decreased from 2.03 to $0.29 \mathrm{~km}^{2}(85.7 \%)$ between 1952 and 2003 [115], and then to around $0.1 \mathrm{~km}^{2}$ in 2011 [113], even though glaciers still covered $0.14 \mathrm{~km}^{2}$ in 2015 [114]. For Colombia, a glacier area reduction of 50\% between the 1950s and 2000 was estimated [111]; the total glacial area was estimated to be $109 \mathrm{~km}^{2}$ for the 1970s [116], $55.4 \mathrm{~km}^{2}$ in the 2000s [111], and $36.8 \mathrm{~km}^{2}$ in 2015 [114]. At Cotopaxi, an ice-covered volcano in Ecuador, relatively stable conditions appeared between 1956 and 1976, followed by a 30\% glacial area loss until 1997 [117]. Cáceres et al. (2004) [118] calculated a 42\% glacial area loss between 1976 and 2006 at Cotopaxi. 
Glaciers in the western and eastern cordilleras of Peru generally underwent a very slow retreat between the 1950s and 1970s [119], which was followed by an accelerated shrinkage between the 1970 s and the late 20 th century $[120,121]$. In comparison, while the retreat rate was relatively low in the western cordilleras, some glaciers in the eastern cordilleras of Peru lost a large portion of their area, for example, the smaller Nevado Tuco in the Cordillera Blanca lost 51\% from 1975 to 2015 [2,33]. Between 1987 and 2010, glaciers in the entire Cordillera Blanca lost 25\% in area [122]. Glaciers in the Cordillera Vilcanota lost up to around $4 \mathrm{~km}^{2}$ annually between 1988 and 2012 [123]. An even greater area loss was observed in the Cordillera Carabaya, where the glacial area decreased by $86 \%$ from 1975 to 2015, resulting in the expansion and the formation of glacial lakes [124]. For the Cordillera Blanca, temperature and precipitation changes alone cannot explain accelerated glacier retreat during the past few decades; in fact, local conditions including morphological (slope, aspect, altitude, etc.) and glaciological characteristics (albedo, surface velocity, etc.) seem to impact glacier mass balance under climate change conditions [44]. Predicting future glacial changes in the Peruvian Andes has proven challenging. For example, while Quelccaya Ice Cap could completely lose its accumulation zone before the end of the 21st century $[125,126]$, some other extensive ice masses such as Nevado Coropuna in the Cordillera Ampato in southern Peru might not disappear completely until the 2120s [127].

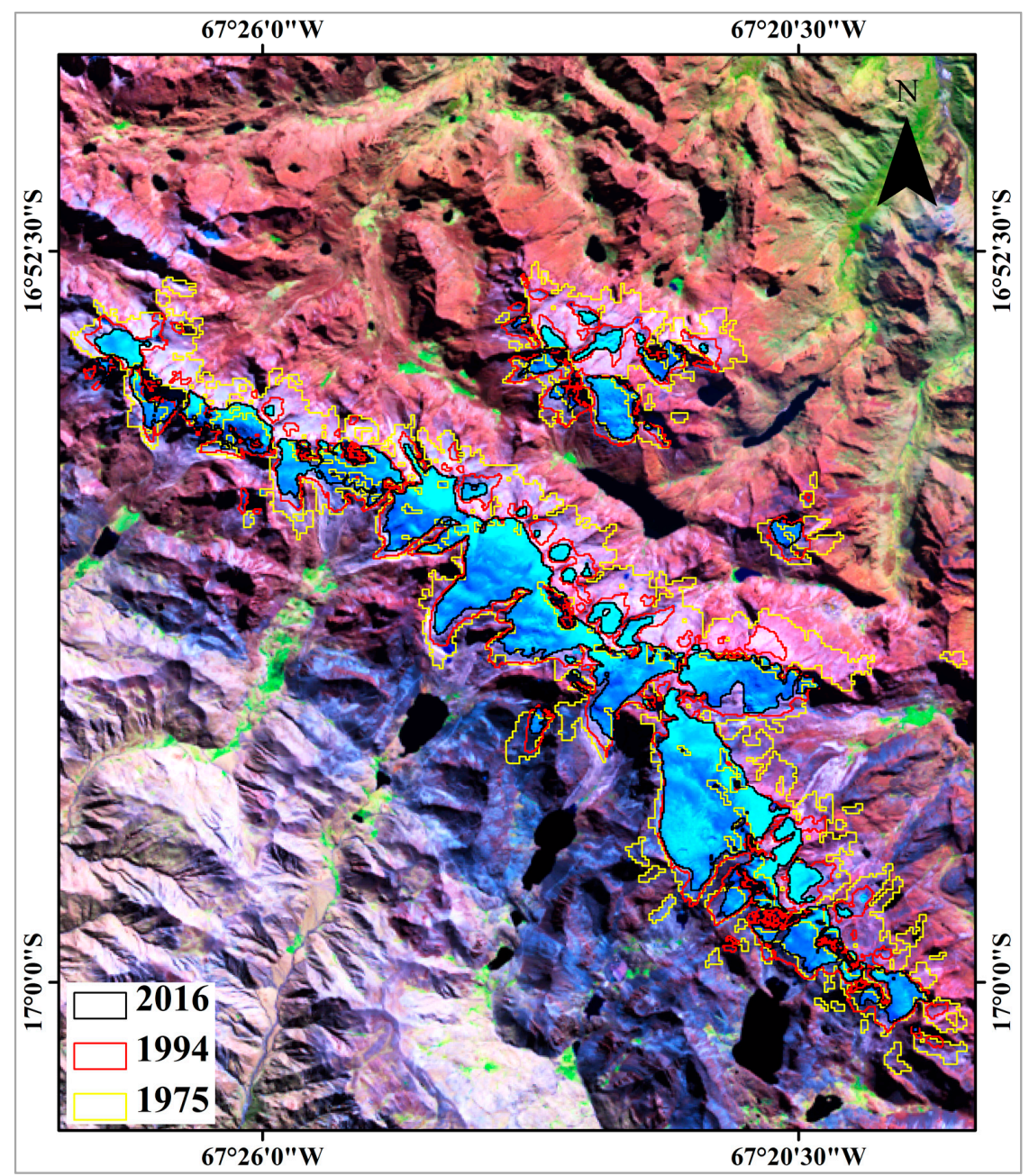

Figure 2. Glacier recession in the Cordillera Tres Cruces in the Bolivian Andes between 1975 and 2016.

In Bolivia, the glacier shrinkage pattern showed similar trends to Peru. In the eastern cordilleras, higher retreat rates were observed on eastern slopes compared with western slopes [124]. In the Cordillera Real, some glaciers lost up to 30\% between 1987 and 2010, and a number of glaciers such as 
Chacaltaya disappeared completely [128,129]. In the cordilleras Real, Apolobamba, and Tres Cruces, the glacier area loss was between $42 \%$ and $47 \%$ between 1986 and 2014 [6]. Our analyses showed that in the Tres Cruces Cordillera, glaciers covered $51.5 \mathrm{~km}^{2}$ in $1975,31.65 \mathrm{~km}^{2}$ in 1994, and $21.1 \mathrm{~km}^{2}$ in 2016, which is a loss in glacial area of 59\% during the entire period between 1975 and 2016 (Figure 2).

\subsection{East Africa}

Some researchers consider African glaciers, particularly on Mt Kilimanjaro, as an icon of global warming [13], owing to their rapid disappearance in recent decades [13,130,131].

Mt Kenya's glaciers retreated dramatically between 1963 and 1987 [10] and further to 1998, when the glacial area had been reduced to $0.4 \mathrm{~km}^{2}$ [132]. Glacier area loss was $15.2 \%$ from 1987 to $1993,31 \%$ from 1993 to 2004, and 40\% from 2004 to 2015, indicating an accelerating glacier recession [133]. We calculated a glacial area of $0.71 \mathrm{~km}^{2}$ for $1986,0.48 \mathrm{~km}^{2}$ for 2002 , and $0.11 \mathrm{~km}^{2}$ for 2015 , a reduction of $84.5 \%$ for the entire period (Figure 3). Lewis Glacier saw a drastic reduction of 2 to $10 \mathrm{~m}$ in thickness between 1974 and 1978 [134], and a 19.8\% reduction in volume between 2004 and 2010 [135]. From 2004 to 2016 , its ice area shrunk by $46 \%$, while its volume decreased by 57\% [136]. Hastenrath (2006) [137] related the near disappearance of Mt Kenya's glaciers to greenhouse effects.

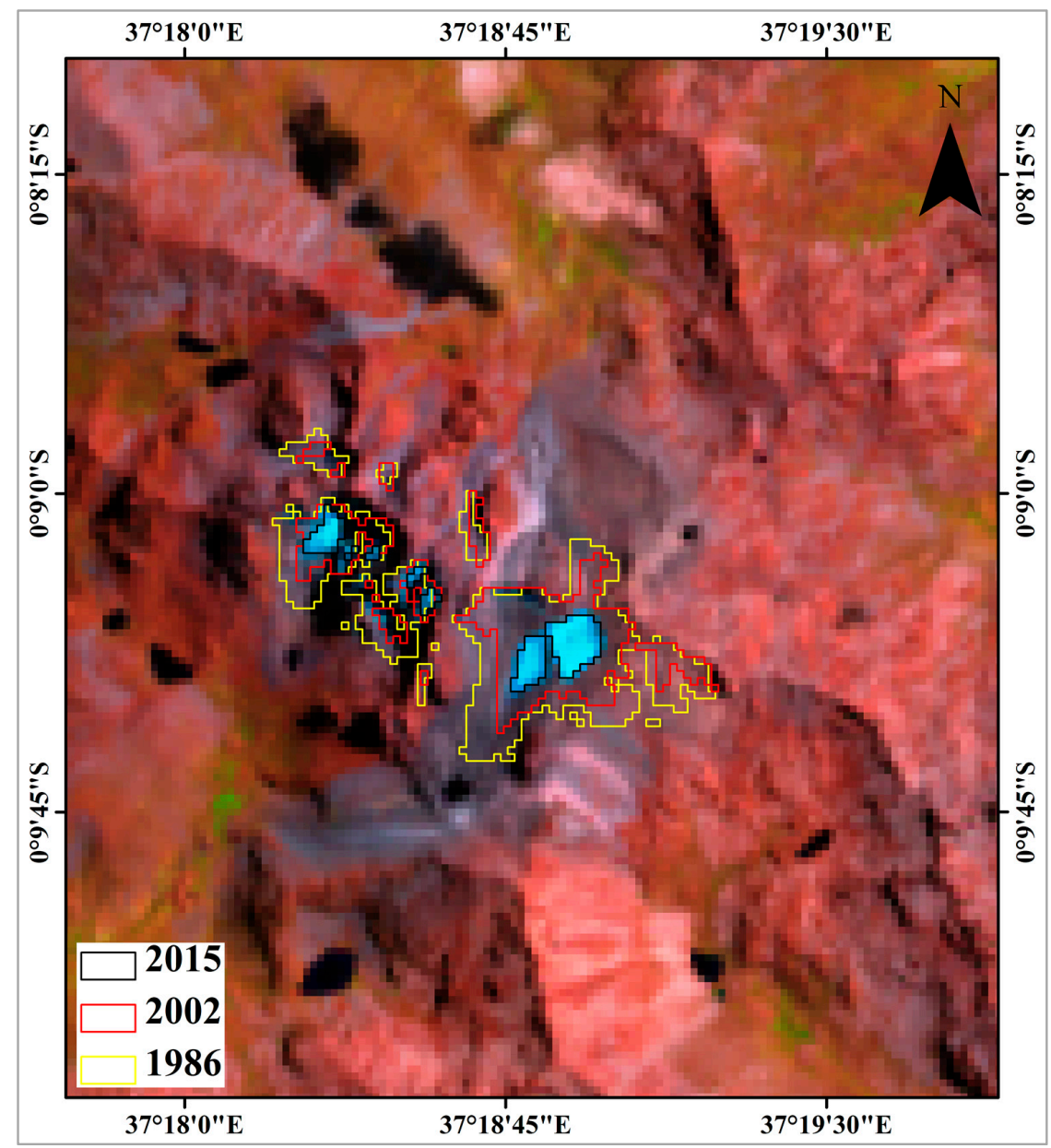

Figure 3. Glacier recession at Mt Kenya in East Africa between 1986 and 2015.

A similar trend of glacial retreat was also observed at Mt Kilimanjaro, where the glacial area decreased from $6.7 \mathrm{~km}^{2}$ to $3.3 \mathrm{~km}^{2}$ between 1953 and 1989 [138], to $2.6 \mathrm{~km}^{2}$ in 2000 [139], and to $1.7 \mathrm{~km}^{2}$ in 2016 based on our analysis. Two different glacier systems can be identified at the mountain: (1) on the plateau above $5700 \mathrm{~m}$, where the retreat of the vertical glacier wall is predominantly controlled by direct solar radiation [11,12] and temperature increase; and (2) at the slopes below $5700 \mathrm{~m}$, where the 
rapid retreat since the early 20th century can only be explained by a change in climate characteristics such as a reduction in specific humidity and an increase in net shortwave radiation accompanied by a decrease in cloudiness and precipitation [140]. Some studies predicted the complete disappearance of all ice at Mt Kilimanjaro by 2020 [139-143].

In the Ruwenzori Mountains, glaciers have been retreating since at least 1957 [144,145]. The glacier terminus of the largest glacier, Speke Glacier, receded by 35-45 m between 1958 and 1977 and by more than $150 \mathrm{~m}$ from 1977 to 1990 [146]. The total glaciated area in the Ruwenzori Mountains declined from around $2 \mathrm{~km}^{2}$ in 1987 to around $1 \mathrm{~km}^{2}$ in 2003, and glaciers are predicted to disappear by 2023 [147]. Mölg et al. (2003a) [11] suggested that the observed differences in glacier recession in the Ruwenzori Mountains are associated with variations in solar incidence; at the same time, Taylor et al. (2006) [147] explained the spatially uniform glacier loss at lower elevations with increased air temperature.

\subsection{Australasia}

Allison and Peterson (1989) [18] estimated that the total glacial area in Papua in the early 1970s was $7.5 \mathrm{~km}^{2}$. Veettil and Wang (2018) [22] found that glacier area decreased from $3.85 \mathrm{~km}^{2}$ in 1988 to $0.58 \mathrm{~km}^{2}$ in 2015, which is a decrease in glacial coverage of 85\% (Figure 4). Klein and Kincaid (2006) [20] assumed that the drastic retreat of Papuan glaciers is a result of the rise in air temperature, which in the tropics is twice the global mean. A few studies hypothesized that the Puncak Jaya glaciers could disappear before 2050 [20-22].

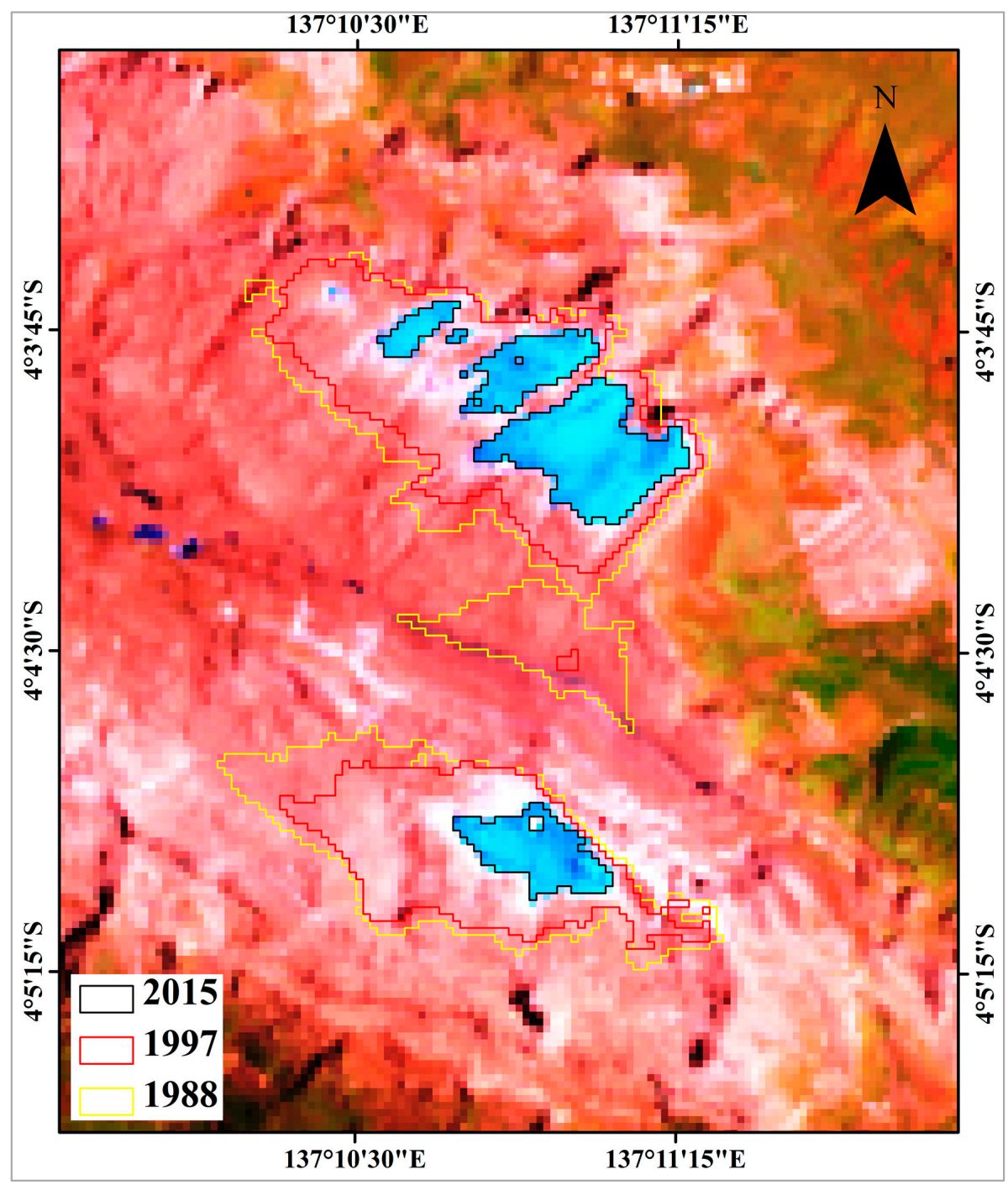

Figure 4. Glacier recession of glaciers in Papua in Australasia between 1988 and 2015. 


\section{Tropical Glaciers: Relevance and Challenges}

More than one-sixth of the global population relies on glaciers and seasonal snowpack for its water supply [148]. Within the tropics, the importance of meltwater from glaciers varies regionally; in the tropical Andes, more people depend on it for domestic usage than in East Africa and Australasia, where glacial areas are small and glaciers count for less than $1 \%$ of all tropical glaciers [149]. In addition, regional precipitation and melt patterns dictate the availability of water to communities. Glacier recession in tropical mountains affects erosion rates, sediment and nutrient fluxes, and the biogeochemistry of water bodies, which in turn affects water quality and ecosystems [150]. Consequently, we explore the regional importance of glaciers in tropical mountain societies, as well as challenges associated with the ice loss.

\subsection{Tropical Andes}

Many ecosystems and communities across the tropical Andes depend on glacier meltwater. The recent trend of a widespread glacier recession and changing water availabilities represents a challenge for these coupled natural and human systems.

\subsubsection{Water Resources}

In the tropical Andes, precipitation regimes vary regionally and strongly determine the importance of glaciers and their meltwater. While two wet seasons occur annually in the inner tropics (e.g., Ecuador), the outer tropics (e.g., Bolivia and Peru) have distinct dry and wet periods [151], where catchments depend on glacial meltwater during the dry season, and any delayed or reduced precipitation-and hence melting-may have serious consequences for water availability [151,152]. At the same time, during the initial stages of enhanced glacial loss, meltwater discharge initially increases and may result in annual flooding events, before the glacial area eventually is too small to produce any significant meltwater volumes. Mark and McKenzie (2007) [152] used stable isotopes and showed that the glacial discharge in the Rio Santa catchment increased by 1.6\% from 2004 to 2006 as a consequence of rapid shrinkage of glaciers in the Cordillera Blanca. Bury et al. (2013) [153] concluded that many catchments in the tropical Andes already passed their peak annual discharge and are now experiencing decreased volumes, which will impact future water availability security. In contrast, the Nevado Coropuna Ice Cap, presently the most extensive ice mass in the tropics, is shrinking considerably slower than previously studies argued, and it has been predicted that it will contribute to water supply until around 2120, which differs from previously predictions by almost 100 years [127].

Numerous studies outline the importance of glaciers as a freshwater resource, and particularly for replenishing aquifers and wetlands in Colombia [154], Ecuador [155], Peru [152,153,156-159], Bolivia [28,160,161], and the tropical Andes in general [41]. Nearly $35 \%$ of the runoff in the arid regions of Peru and Chile is supplied by meltwater from glaciers and snow [162]. As a result of limited rainfall at high elevations, almost all Andean cities above $2500 \mathrm{~m}$ depend on glacier meltwater as a freshwater resource to some degree [163]. A study about water resources in the capital La Paz in Bolivia showed that between 1963 and 2006, the annual contribution of glaciers to local freshwater resources was 15\%, with $14 \%$ during the wet season and $27 \%$ during the dry season, highlighting the importance of glacier meltwater, particularly during the drier times [161]. A similar observation from the Cordillera Blanca revealed that the disappearance of glaciers may reduce the annual average discharge by between $2 \%$ and $30 \%$, depending on the catchment; in seven of nine studied catchments within the Cordillera Blanca, the dry season discharge showed a trend of decrease in recent years [157].

\subsubsection{Natural Hazards}

Glacier shrinkage since the late 20th century has resulted in the formation and expansion of numerous glacial lakes throughout the tropical Andes $[6,124,164,165]$, which might pose a potential threat in the form of glacial lake outburst floods (GLOFs) — a flooding of the lake waters down-valley after the breaching of the debris/ice dam [165]. In the tropical Andes, GLOF potential has been identified 
for several locations in the cordilleras Blanca and Carabaya of Peru [124,164,165], and in the cordilleras Apolobamba, Real, and Tres Cruces of Bolivia [6].

The threat from landsliding in recently deglaciated areas is widespread throughout the tropical Andes [166,167]. An extreme rainfall in 1998 that followed a prolonged glacier retreat at Nevado Salcantay in the Eastern Cordillera of Peru triggered a landslide of mainly glacial sediment [168]. The landslide reached the Vilcanota River, where it created a $70 \mathrm{~m}$ high debris dam and caused 100 million dollars in damage at a hydroelectric power plant. Vilímek et al. (2015) [169] discussed the impacts of a GLOF resulting from a mass movement of about 500,000 $\mathrm{m}^{3}$ of ice and rock at Mt Hualcan in the Chucchun Valley of the Cordillera Blanca in Peru in 2010 (Figure 5). Despite no fatalities being reported, some houses, roads, bridges, and a water treatment plant were destroyed, affecting the local population for some years. Similar conclusions were presented for a GLOF that had occurred in the Chucchun Valley in 2010 [170].
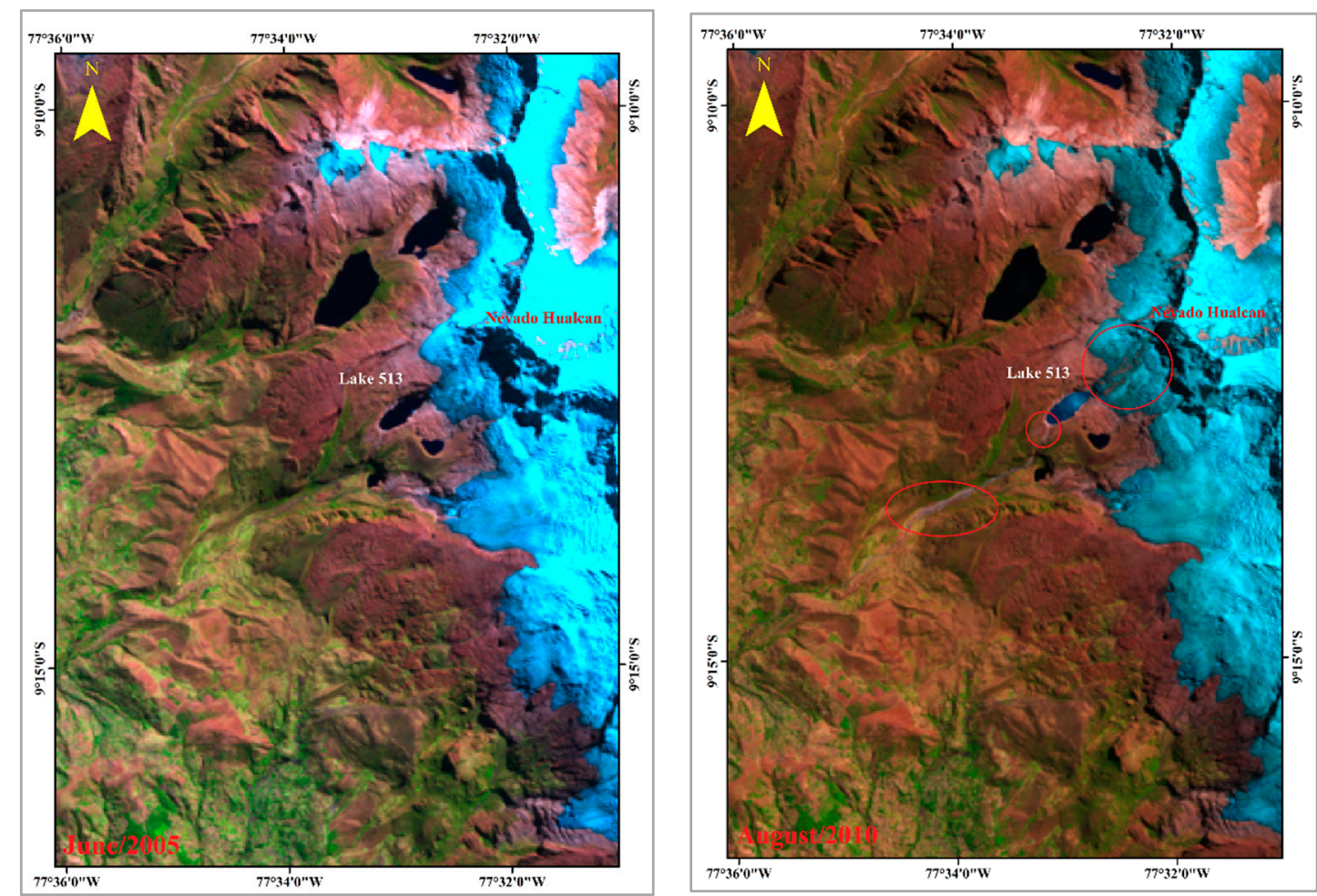

Figure 5. The Chucchun Valley in the Cordillera Blanca, Peru, before (left) and after (right) the 2010 GLOF at Lake 513. Movement of sediments and the direction of ice avalanches are highlighted.

\subsubsection{Ecosystems}

Many ecosystems in the tropical Andes are influenced by the presence of glaciers. The wetlands or páramos found between the Cordillera Merida in Venezuela and the Huancabamba Depression in northern Peru represent a complex and fragile ecosystem that is fed also by glacier meltwater and provides water to other ecosystems, as well as to human societies along the Pacific coast [151]. Many rivers here are either glacier- or páramos-fed [171]. Furthermore, the wider páramos-ecosystem consists of a collection of smaller neotropical alpine grassland ecosystems that all play a key role in the hydrology of the northern Andes and the Amazon Basin. The water yield of a smaller páramos basin $\left(<3 \mathrm{~km}^{2}\right)$ can reach $67 \%$ of the total rainfall [172]. However, the páramos are becoming increasingly vulnerable to a warming climate and loss of glacier area [172-174]. The effect of glacier shrinkage on páramos is still unclear, but a decrease in glacier runoff might accelerate the transition from a wet páramos to a dry páramos [172,175]. The biodiversity of the dry páramos in Ecuador is threatened by a changing hydrology [176]. When assessing the consequences of a decreased glacier meltwater 
contribution for freshwater resources, agriculture and hydropower production in the Cordillera Blanca of Peru between 1987 and 1995, a change in wetland status was observed: (1) glacier shrinkage was associated with increased wetland area; and (2) an increase in mean annual stream discharge in the previous twelve months increased the wetland area [177]. High elevation wetlands in the Bolivian Cordillera Real revealed a similar transition: perennial and complex wetlands experienced strong drying processes, whereas a number of smaller temporary wetlands were formed owing to the rapid melting of glaciers [178].

The disappearance of the alpine glaciers is predicted to cause migration of plant species (e.g., Pleurodema, Telmatobius, Liolaemus, Diuca speculifera) to higher elevations, and this colonizing of new high elevation habitats would introduce competition for and displacement of existing species [171]. The upward migration of 54 vascular plants and 39 lichen and bryophytes species colonizing rocks in recently deglaciated areas above $5400 \mathrm{~m}$ was observed in the Cordillera Vilcanota in Peru [179]. However, the dynamics of primary succession is slow compared with the decline in glacier coverage resulting from accelerated warming [180]. As a consequence of glacial recession in the Cordillera Blanca of Peru, the entire treeline migrated to higher elevations [181]. In many tropical mountains, the glacial recession also resulted in land use changes [182]. More research on biodiversity and ecosystem consequences of successional changes is needed, particularly on direct effects of glacier retreat in higher elevations, and of indirect effects from socio-ecological drivers at lower elevations [182].

Animals may also relocate to higher elevations; for example, some amphibians such as anurans (frogs and toads) have been found in recently deglaciated terrain in Peru [179]. Some of these new anurans species have been associated with the fungal pathogen Batrachochytrium dendrobatidis, which has previously been related to the disappearance of various amphibians throughout South America [179]. As such, the invasive species can possess a threat from carried pathogens that might infect the native species. Tropical glaciers are nesting grounds for some bird species (e.g., Idiospar speculifera), and the ongoing loss of tropical glaciers may have a negative effect on biodiversity with regard to the loss of habitat [183].

Increased meltwater volumes during the initial stage of a glacier recession can impact aquatic ecosystems. A decrease in diversity of the benthic fauna has been observed in several equatorial high-elevation Andean streams [184]. In some lakes of Ecuador, algal blooms and eutrophication from toxin-producing microorganisms have been noticed [185], and populations of the planktonic thalassiosiroid diatom Discostella stelligera have increased [186]. Such changes can influence the nutrient cycle and food web structure in these aquatic ecosystems [186].

\subsubsection{Human and Animal Health}

Natural hazards, such as avalanches, GLOFs, and landsliding, have caused fatalities and injuries throughout the tropical Andes. For example, two avalanches in 1962 and 1970 at Nevado Huascaran (Cordillera Blanca, Peru) caused the deaths of more than 25,000 people [24]. Glacier recession has also been related to the spreading of vector-borne diseases such as Malaria [187,188] and Zika [189], which was explained with the formation of small meltwater ponds that offer ideal conditions for breading insects. Furthermore, it can be argued that the particulate materials found in glacier ice, now released into rivers and streams, can be potentially harmful to human health, if they are not filtered out.

\subsubsection{Agriculture and Mining}

The glacier disappearance throughout the tropical Andes affects hydrological regimes and water availability for agricultural and industrial purposes. The decline in agricultural productivity in the Cotacachi region in Ecuador has been related to glacier recession [190], and in the Cordillera Blanca in Peru, a reduction in agricultural production could be disastrous for food security and economy [162]. In Peru, the majority of the human population-and economic activity-is concentrated on the western dry side of the Andes, where water resources are highly dependent on glacier meltwater [162]. Here, with increasing demand for food for a growing population, agricultural land is expanding. In the 
Department of Ancash, which includes the Parc Nacional Huascaran, agricultural land area has increased from 46,000 hectares in 1995 to 353,000 hectares in 2000 [191]. Mark et al. (2010) [192] discussed the influence of climate change and glacier shrinkage on agriculture and livestock along the length of the Rio Santa and called for adaptation strategies in the future; their surveys revealed that a large majority of households were aware of the rapid glacier recession and climate change impacts on freshwater resources and agro-pastoral production.

Mining activities throughout the tropical Andes require increasing water supplies, which includes meltwater from glaciers $[193,194]$. Additionally, these mining activities produce air pollutants such as black carbon that result in a darkening of glaciers, enhancing the general glacier shrinkage, but increasing meltwater runoff $[8,132]$. The contamination from mining activities resulted in health risks for ecosystems and communities.

\subsubsection{Hydropower}

Most of the countries in the tropical Andes depend on meltwater from ice and snow to meet the demand for electricity production; around 50\% in Ecuador, and almost $80 \%$ in Peru [162]. In Ecuador, hydropower generation largely depends on the water originating in the páramos, which depend themselves on glacier meltwater influx [195]. In the fast growing La Paz-El Alto region in Bolivia, 75\% of the electric power is generated by eight power plants in the Zongo Valley [196], fed by the Zongo and Chacaltaya glaciers, which showed high negative mass balances for many years [197]; by 2009, Chacaltaya Glacier, one of the highest glaciers in the Andes, had totally disappeared.

It is very likely that the continuing decrease in glacier coverage will result in significant changes in the economy of affected countries [148], particularly if precipitation alone cannot provide sufficient stream flow. Kronenberg et al. (2016) [5] investigated the glacier-climate interactions in the Cordillera Vilcanota in Peru and warned about serious consequences of a future reduction in precipitation, glacier shrinkage, and unstable runoff for the hydropower sector. Nevertheless, an increase of around $300 \%$ in planned hydroelectric dam projects throughout the region was noticed [151]—a surprise in the light of the fact that many of the new reservoirs would also depend on glacier meltwater.

\subsubsection{Tourism}

Impacts of glacier recession on the tourism sector have often been underestimated in discussions about climate change and glacier loss throughout the tropics [198], despite that many recreational activities are associated with the snow-covered mountains. The cordilleras of Peru have received increasing attention from mountain climbers from all over the world for the last 30 years, and the associated infrastructure in the form of hotels, resorts, and transportation boomed during this period [165,199]. Every year, more than 100,000 tourists visit Huascarán National Park in the Cordillera Blanca and the city of Huaraz [200]. At Chacaltaya Glacier in Bolivia, the first ski lift in South America and also the highest in the world was built in 1939 [165,201]. However, after 70 years, the glacier had disappeared by 2009 and the resort had to close. It was suggested that the Bolivian authorities could maintain this location as a 'national memorial site' or as an iconic place [201]. The disappearance of the Cotacachi Glacier in Ecuador lowered water levels in the crater lake Cuicocha, which affected boat tour tourism, a major attraction [190]. Last, but not least, potential GLOF risk at some glacial lakes that formed as a consequence of the recent recession may influence tourists in their decision to visit these areas.

On the other hand, the tourism industry itself affects glacial ecosystems and local communities through human disturbances such as littering and pollution [202]. For Bolivia, it was suggested that future tourism activities should focus on cultural destinations and colorful festivals rather than tour packages to disappearing glaciers [203]. On the other hand, formerly glaciated landscapes are still beautiful and attractive to tourists [201] and would allow for an educational tourism. 


\subsubsection{Traditions and Spirituality}

Numerous mountain glaciers throughout the tropical Andes are associated with religious beliefs and festivals. In the Sinacara Valley of the Peruvian Andes, at the bottom of the Qulqipunku Glacier at $4500 \mathrm{~m}$, the annual 'snow festival' (known as Qoyllur Rit'i) combines Catholic, Incan, and other indigenous beliefs. By 2016, the glacier had receded so far that a relocation of the festival to even higher elevations was considered; however, the authorities decided for an event date later in the year, when snowfall would reach the elevation of the traditional location [204]. The highest known ceremonial site in the world is on the summit of Mt Llullaillaco in northern Argentina, where three well-preserved frozen mummies of Inca children were discovered at $6700 \mathrm{~m}$ [205]. In the ancient Inca culture, the disappearance of snow-covered peaks signified the end of the world. Eventually, the ongoing glacier recession throughout the tropical Andes may result in the loss of traditions at the local and regional scale affecting cultural identities.

\subsubsection{Conflicts and Migrations}

Glacier disappearances and recessions resulting in reduced water resources have previously been related to conflicts $[206,207]$ and migrations of human populations [198,208]. Conflicts may arise at different levels and scales, for example, between countries, among communities, or between a community and a hydroelectric company, particularly when a dependency on glacier meltwater in a region with highly seasonal precipitation exists [209].

Once the water resources become too vulnerable, local communities previously dependent on snowmelt will be forced to migrate under a changing climate, seeking more available water resources, agricultural land, and lower exposure to vector-borne diseases that may arise with a warming climate $[142,210,211]$. It is believed that the glacier melting in the tropical Andes will have a larger negative impact on small-scale societies, such as the indigenous people (e.g., Quechua people in the Peruvian Andes), who may be forced to migrate [211,212].

\subsection{East Africa}

Despite being on a much smaller scale than in the tropical Andes, the glaciers of East Africa also contribute to stream flow, and hence are an important water resource. Therefore, glacier recession threatens ecosystems and human activities.

\subsubsection{Water Resources}

A constant decrease in water availability has been observed in villages located in the foothills of glaciated mountains in East Africa [213]. Around Mt Kilimanjaro, many canals in the foothills have dried up and water levels of streams are generally lower, causing conflicts over access to water [214]. However, regionally, the negative impact of reduced glacier meltwater volumes is considered to be less of a problem in the Rwenzori Mountains, because here, glaciers contribute less than $2 \%$ to the total discharge of the principal rivers during both the dry and wet season $[149,215]$.

\subsubsection{Ecosystems}

Previously glaciated mountains in East Africa witnessed vegetation succession after the loss of ice coverage. The slopes of Tyndall Glacier on Mt Kenya, which were still glacier-covered in the 1970s, have been invaded by pioneer species such as Senecio keniophytum, Arabis alpine, and Agrostis trachyphylla since the late 2000s [216]. The rate of upslope migration of the vegetation was 2.1 to $4.6 \mathrm{~m} /$ year between 1958 and 1997, similar to the glacier retreat rate of $2.9 \mathrm{~m} /$ year. Between 1997 and 2002, vegetation advanced at an accelerated rate of 6.4 to $12.2 \mathrm{~m}$ /year; over the same period, the glacier retreat rate had increased to $9.8 \mathrm{~m} /$ year [216]. Zawierucha et al. (2018) [217] expressed concerns that, as a result of the glacier recession, the presence of a large number of rotifers on glaciers in Uganda and their extinction in the near future is inevitable. 


\subsubsection{Human Health}

The ongoing glacial recession at the East African mountains led to the formation of meltwater ponds, which can be breeding grounds for disease-carrying insect species such as the mosquito, particularly when occurring alongside increasing air temperature. In 1997/98, a strong El Nino had been associated with the retreat of tropical glaciers worldwide; during this period, there was an increase in cases of cholera, malaria, and other diseases in the East African mountains [218]. It is unclear, however, if the former caused the latter.

\subsubsection{Agriculture}

Agriculture is a major contributor to the economy of East African countries. A reduced snow cover and extensive melting of ice were identified as being one of the reasons for variations in runoff and soil moisture content, which would eventually affect crops [219]. For example, coffee production around Mt Kilimanjaro suffered from low rainfall as well as reduced glacial runoff [220].

\subsubsection{Tourism}

The glaciated mountains of East Africa attract high numbers of tourists every year [221] and consequently, tourism contributes significantly to local economies. However, it has been predicted that the plateau ice at Mt Kilimanjaro, which is of exceptionally high tourist potential in Tanzania, would disappear in the mid-21st century, resulting in a considerably reduced touristic appeal of the mountain [12]. In Uganda, the recession of the Rwenzori glaciers was expected to negatively impact the eco-tourism sector [222].

\subsection{Australasia}

It has been predicted that the Australasian glaciers will disappear in the 2020s under the current climate conditions $[20,22]$. While their small extent contributes an insignificant amount of water to river discharge [149], negative impacts on local ecosystems, such as natural habitat loss or emergence of disease-causing agents, must be expected.

The aerial deposition of black carbon on glacier surfaces and their related darkening absorbs more solar radiation, which results in enhanced melting. This is a concern for the survival of the glaciers of Papua, particularly after the expansion of mining activities throughout the region [22]. Other sources for dust particles on these glaciers might be wood burning in Kalimantan, Sumatra, and even northern Australia.

\section{Future “Darkened Peaks"?}

Many studies have documented the ongoing disappearance of tropical glaciers worldwide [223,224]. While the retreat in in some regions of South America is still relatively slow [2], the glaciers in East Africa [15] and Australasia [20,22] are close to extinction. While a few authors assume regional factors behind this ice loss [225], many others affirmed global climate change, particularly temperature rise, as the main culprit [223].

Even though a reduction in glacier area was observed since the Little Ice Age (LIA) throughout the tropics, the rate of shrinkage generally increased in the late 1970s [2,3,8], particularly in lower elevations [1]. In the process of this glacier recession, the additional darker land surface area that absorbs higher rates of radiation now accelerates further glacier loss-positive feedback [41]. On the other side, ice-core records supported the view that temperatures on and near glacier surfaces increase more at higher elevations [223]. As most of the tropical glaciers are located above $4800 \mathrm{~m}$, the future of these snow-covered peaks could be their darkening. Without a doubt, the warming at higher rates in mountain regions in general is concerning $[41,42,226]$, and even more so in the tropics where glaciers seem to be more sensitive to temperature variations. Even though a hiatus in global warming was proposed in some studies [227], it does not seem to have influenced tropical mountain glaciers at 
high altitudes [2] and these glaciers continued to shrink. Furthermore, smaller glaciers respond to a warming climate faster than larger sized ones [223], which is evident from the near disappearance of glaciers in Papua [20,22].

\section{Adaptation Strategies}

The negative impacts of the glacier loss on ecological and socio-economic systems require the development of adaptation strategies ranging from large-scale general management plans to small-scale specialized solutions.

Emmer and Vilímek $(2013,2014)[228,229]$ explained that before adaptation strategies related to the GLOF hazard mainly in the Andes of Peru and Bolivia could be developed and implemented, a proper assessment of the hazard is necessary. The authors recommended a two-phase GLOF assessment: (1) estimate the probability of water release from a given glacial lake based on a lake and breach hazard assessment; and (2) identify the areas at risk in a downstream hazard assessment. It has been demonstrated that implementations of adaptation strategies related to GLOFs must involve affected communities and risk hazard awareness. For example, after a rock-ice avalanche had initiated a GLOF at Lake 513 near Nevado Hualcan in the Cordillera Blanca of Peru, Carey et al. (2012b) [170] discussed an integrated socio-environmental framework for climate change adaptation in glacial lake environments and concluded that only the participation of stakeholders from multiple levels-international, national, and local—promises success. The authors [170] proposed "a holistic approach for integrating disaster disk reduction and climate change adaptation."

In the light of decreasing glacier meltwater volumes, alternative water supply resources gain importance. However, these can be very expensive or impractical to implement, owing to an increased demand and high per-capita consumption [41]. On the other hand, relatively inexpensive methods, such as rain harvesting, may not be able to meet the additional demands. The World Bank (2014b) [230] presented recommendations to tackle the impacts of climate change and glacier shrinkage on water resources in Bolivia, Ecuador, and Peru: (1) strengthen agricultural practices (including sustainable irrigation systems); (2) improve irrigation infrastructure; (3) reduce water losses for the water distribution system of large urban areas (e.g., La Paz and El Alto in Bolivia); (4) increase the resilience of key glaciered basins with ecosystem restoration and conservation at high-altitude, and increase irrigation efficiency at low altitude; (5) install glacier monitoring stations for the better understanding of glacier retreat; and (6) develop investment plans, integrated watershed management plans, and strategic development plans for changing climate conditions. However, expected demographic changes are likely to outpace the impact of climate change on water resources and need to be considered in policy making for the future [231].

\section{Conclusions}

Tropical mountain glaciers are shrinking globally. Currently, more than $99 \%$ of the tropical glaciers worldwide are found in the South American Andes, with the remaining ice being located in East Africa and Australasia. Global, regional, and local climates influence the stability of these tropical glaciers. Additionally, non-climate factors such as volcanic dust and industrial black carbon drive the glacial loss.

The importance of tropical glaciers may vary regionally or locally. Glacier meltwater contributes to water supply, agriculture, and hydropower generation throughout the tropical Andes, and some glaciers represent important cultural sites or are magnets in outdoor tourism. Their social-economic significance is particularly visible in the South American Andes. The ongoing glacier recession across the tropics has many direct and indirect effects on coupled human and natural systems in the form of ecosystem changes, draughts, and floods, as well as water shortages, hazards, and economic loss. In some regions such as Bolivia and Peru, the glacier shrinkage has already resulted in conflicts and migration. The increasing darkening of ice-covered tropical mountains only enhances recession, and thus the impact of resulting challenges. 
While the increase in water availability resulting from initial glacier melting might enhance economic opportunities and productivity, it needs to be understood that once the glacier recession reaches a threshold, meltwater runoff will decrease dramatically. Hence, the challenges related to glacier loss call for rigorous mitigation and adaptation strategies that include stakeholders at multiple levels and consider short-, medium-, and long-term solutions. Therefore, glaciers in the tropical Andes must be systematically monitored, observed changes must be assessed, and these data must be considered in planning and management strategies. Such strategies must merge the conservation of tropical glacier water reservoirs ('Water Towers') with the preservation of ecosystems and traditions; for example, by implementing new or extending existing protected areas. Glaciers are not only moving ice masses; instead, individual glaciers or wider glaciated landscapes can be seen as geomorphosites-"geomorphological landforms that have acquired a scientific, cultural/historical, aesthetic and/or social/economic value due to human perception or exploitation" [232].

Author Contributions: Both authors contributed equally to the text; B.K.V. prepared the figures.

Funding: This research received no external funding.

Acknowledgments: Global Land Ice Measurement from Space (GLIMS) initiative for providing the Randolph Glacier Inventory data to the scientific community; USGS for providing satellite data.

Conflicts of Interest: The authors declare no conflict of interest.

\section{References}

1. Kaser, G.; Osmaston, H. Tropical Glaciers; Cambridge University Press: Cambridge, UK, 2002.

2. Veettil, B.K.; Wang, S.; De Souza, S.F.; Bremer, U.F.; Simões, J.C. Glacier monitoring and glacier-climate interactions in the tropical Andes: A review. J. South Am. Earth Sci. 2017, 77, 218-246. [CrossRef]

3. Vuille, M.; Francou, B.; Wagnon, P.; Juen, I.; Kaser, G.; Mark, B.G.; Bradley, R.S. Climate change and tropical Andean glaciers: Past, present and future. Earth-Sci. Rev. 2008, 89, 79-96. [CrossRef]

4. Richardson, S.D.; Reynolds, J.M. An overview of glacial hazards in the Himalayas. Quat. Int. 2000, 65, 31-47. [CrossRef]

5. Kronenberg, M.; Schauwecker, S.; Huggel, C.; Salzmann, N.; Drenkhan, F.; Frey, H.; Giráldez, C.; Gurguiser, W.; Kaser, G.; Juen, I.; et al. The projected precipitation reduction over the Central Andes may severely affect Peruvian glaciers and hydropower production. Energy Proced. 2016, 97, 270-277. [CrossRef]

6. Cook, S.J.; Kougkoulos, I.; Edwards, L.A.; Dortch, J.; Hoffmann, D. Glacier change and glacial lake outburst flood risk in the Bolivian Andes. The Cryosphere 2016, 10, 2399-2413. [CrossRef]

7. Vuille, M.; Carey, M.; Huggel, C.; Buytaert, W.; Rabatel, A.; Jacobsen, D.; Soruco, A.; Villacís, M.; Yarlequé, C.; Timm, O.E.; et al. Rapid decline of snow and ice in the tropical Andes - Impacts, uncertainties and challenges ahead. Earth-Sci. Rev. 2018, 176, 195-213. [CrossRef]

8. Rabatel, A.; Francou, B.; Soruco, A.; Gómez, J.; Cáceres, B.; Ceballos, J.L.; Basantes, R.; Vuille, M.; Sicart, J.-E.; Huggel, C.; et al. Current state of glaciers in the tropical Andes: A multi-century perspective on glacier evolution and climate change. The Cryosphere 2013, 7, 81-102. [CrossRef]

9. Hastenrath, S.; Kruss, P.D. The dramatic retreat of Mount Kenya's glaciers between 1963 and 1987: Greenhouse forcing. Ann. Glaciol. 1992, 16, 127-133. [CrossRef]

10. Hastenrat, S.; Kruss, P.D. Greenhouse indicators in Kenya. Nature 1992, 355, 503-504. [CrossRef]

11. Mölg, T.; Georges, C.; Kaser, G. The contribution of increased incoming shortwave radiation to the retreat of the Rwenzori Glaciers, East Africa, during the 20th century. Int. J. Clim. 2003, 23, 291-303. [CrossRef]

12. Mölg, T.; Hardy, D.R.; Kaser, G. Solar-radiation-maintained glacier recession on Kilimanjaro drawn from combined ice-radiation geometry modeling. J. Geophys. Res. Biogeosciences 2003, 108, 4731. [CrossRef]

13. Kaser, G.; Hardy, D.R.; Mölg, T.; Bradley, R.S.; Hyera, T.M. Modern glacier retreat on Kilimanjaro as evidence of climate change: observations and facts. Int. J. Clim. 2004, 24, 329-339. [CrossRef]

14. Mölg, T.; Hardy, D.R. Ablation and associated energy balance of a horizontal glacier surface on Kilimanjaro. J. Geophys. Res. Biogeosciences 2004, 109. [CrossRef]

15. Thompson, L.G.; Brecher, H.H.; Mosley-Thompson, E.; Hardy, D.R.; Mark, B.G. Glacier loss on Kilimanjaro continues unabated. Proc. Acad. Sci. 2009, 106, 19770-19775. [CrossRef] [PubMed] 
16. Allison, I. Morphology and dynamics of the tropical glaciers of Irian Jaya. Zeitschrift für Gletscherkunde und Glazialgeology 1974, 10, 129-152.

17. Allison, I.; Kruss, P. Estimation of Recent Climate Change in Irian Jaya by Numerical Modeling of Its Tropical Glaciers. Arct. Alp. 1977, 9, 49. [CrossRef]

18. Allison, I.; Peterson, J.A. Glaciers of Irian Jaya, Indonesia. In Satellite Image Atlas of Glaciers of the World; Williams, R.S., Jr., Ferrigno, J.G., Eds.; US Government Printing Office: US Geological Survey, Washington, DC, USA, 1998.

19. Prentice, M.L.; Glidden, S. Glacier crippling and the rise of the snowline in the western New Guinea (Papua Provice, Indonesia) from 1972 to 2000. In Altered Ecologies: Fire, Climate and Human Influence on Terrestrial Landscapes; ANU Press: Canberra, Australia, 2000.

20. Klein, A.G.; Kincaid, J.L. Retreat of glaciers on Puncak Jaya, Irian Jaya, determined from 2000 and 2002 IKONOS satellite images. J. Glaciol. 2006, 52, 65-79. [CrossRef]

21. Kincaid, J.L. An Assessment of Regional Climate Trends and Changes to the Mt. Jaya Glaciers of Irian Jaya. Master's Thesis, Texas A\&M University, TX, USA, 2007.

22. Veettil, B.K.; Wang, S.-S. State and fate of the remaining tropical mountain glaciers in australasia using satellite imagery. J. Sci. 2018, 15, 495-503. [CrossRef]

23. Francou, B. New evidence for an ENSO impact on low-latitude glaciers: Antizana 15, Andes of Ecuador, $0^{\circ} 28^{\prime}$ S. J. Geophys. Res. Biogeosciences 2004, 109, D18. [CrossRef]

24. Morales-Arnao, B. Glaciers of Peru. In Satellite Image Atlas of the World: Glaciers of South America; Williams, R.S., Jr., Ferrigno, J.G., Eds.; U.S. Government Printing Office: Washington, DC, USA, 1999.

25. Young, J.A.T.; Hastenrath, S. Glaciers of Africa. In Satellite Image Atlas of the World: Glaciers of South America; Williams, R.S., Jr., Ferrigno, J.G., Eds.; U.S. Government Printing Office: Washington, DC, USA, 1999.

26. Intergovernmental Panel on Climate Change. Climate Change 2007: The Physical Science Basis; Intergovernmental Panel on Climate Change: Geneva, Switzerland, 2007.

27. Intergovernmental Panel on Climate Change. Impacts, Adaptation and Vulnerability; Cambridge University Press: Cambridge, UK, 2007.

28. Ribstein, P.; Tiriau, E.; Francou, B.; Saravia, R. Tropical climate and glacier hydrology: a case study in Bolivia. J. Hydrol. 1995, 165, 221-234. [CrossRef]

29. Arnaud, Y.; Muller, F.; Vuille, M.; Ribstein, P. El Niño-Southern Oscillation (ENSO) influence on a Sajama volcano glacier (Bolivia) from 1963 to 1998 as seen from Landsat data and aerial photography. J. Geophys. Res. 2001, 106, 773-784. [CrossRef]

30. Veettil, B.K.; Maier, É.L.B.; Bremer, U.F.; De Souza, S.F. Combined influence of PDO and ENSO on northern Andean glaciers: A case study on the Cotopaxi ice-covered volcano, Ecuador. Clim. Dyn. 2014, 43, 3439-3448. [CrossRef]

31. Veettil, B.K.; Bremer, U.F.; Souza, S.F.; Maier, É.L.B.; Simões, J.C. Variations in annual snowline and area of an ice-covered stratovolcano in the Cordillera Ampato, Peru, using remote sensing data (1986-2014). Geocarto Int. 2015, 31, 544-556. [CrossRef]

32. Veettil, B.K.; Bremer, U.F.; Souza, S.F.; Maier, É.L.B.; Simões, J.C. Influence of ENSO and PDO on mountain glaciers in the outer tropics: case studies in Bolivia. Theor. Appl. Climatol. 2016, 125, 757-768. [CrossRef]

33. Veettil, B.K.; Wang, S.; Bremer, U.F.; Souza, S.F.; Simões, J.C. Recent trends in annual snowline variations in the northern wet outer tropics: Case studies from southern Cordillera Blanca, Peru. Theor. Appl. Climatol. 2017, 129, 213-227. [CrossRef]

34. Maussion, F.; Gurgiser, W.; Großhauser, M.; Kaser, G.; Marzeion, B. ENSO influence on surface energy and mass balance at Shallap Glacier, Cordillera Blanca, Peru. The Cryosphere 2015, 9, 1663-1683. [CrossRef]

35. Garreaud, R.D. The Andes climate and weather. Adv. Geosci. 2009, 22, 3-11. [CrossRef]

36. Garreaud, R.D.; Vuille, M.; Compagnucci, R.; Marengo, J. Present-day South American climate. Palaeogeogr. Palaeoclim. Palaeoecol. 2009, 281, 180-195. [CrossRef]

37. Bedoya-Soto, J.M.; Poveda, G.; Trenberth, K.E.; Velez-Upegui, J.J. Interannual hydroclimatic variability and the 2009-2011 extreme ENSO phases in Colombia: from Andean glaciers to Caribbean lowlands. Theor. Appl. Climatol. 2018, 135, 1531-1544. [CrossRef] 
38. Ebbesmeyer, C.C.; Cayan, D.R.; McLain, D.R.; Nichols, F.H.; Peterson, D.H.; Redmond, K.T. 1976 Step in the pacific climate: forty environmental changes between 1968-1975 and 1974-1984. In Proceedings of the Seventh Annual Pacific Climate Workshop, California Department of Water Resources, Interagency Ecological Studies Program, Asilomar, CA, USA, 10-13 April 1990.

39. Ramaswamy, V.; Hurrel, J.W.; Meehl, G.A.; Philips, A.; Santer, B.D.; Schwarzkopf, M.D.; Seidel, D.J.; Sherwood, S.C.; Thorne, P.W. Why do temperatures vary vertically (from the surface to the stratosphere) and what do we understand about why they might vary and change over time? In Temperature Trends in the Lower Atmosphere: Steps for Understanding and Reconciling Differences (SAP 1.1); Karl, T.R., Hassol, S.J., Miller, C., Murray, W., Eds.; US Climate Change Science Program: Washington, DC, USA, 2006.

40. Randall, D.A.; Wood, R.A.; Bony, S.; Colman, R.; Fichefet, T.; Fyfe, J.; Kattsov, V.; Pitman, A.; Shukla, J.; Srinivasan, J.; et al. Climate Models and Their Evaluation. In Climate Change 2007: The Physical Science Basis. Contribution of Working Group I to the Fourth Assessment Report of the Intergovernmental Panel on Climate Change; Solomon, S., Qin, D., Eds.; Cambridge University Press: Cambridge, UK, 2007.

41. Bradley, R.S.; Vuille, M.; Diaz, H.F.; Vergara, W. Threats to water supply in the tropical Andes. Science 2006, 312, 1755-1756. [CrossRef]

42. Mountain Research Initiative EDW Working Group. Elevation-dependent warming in mountain regions of the world. Nature Clim. Chang. 2015, 5, 424-430. [CrossRef]

43. Vicente-Serrano, S.M.; López-Moreno, J.I.; Correa, K.; Avalos, G.; Bazo, J.; Azorin-Molina, C.; Domínguez-Castro, F.; El Kenawy, A.; Gimeno, L.; Nieto, R.; et al. Recent changes in monthly surface air temperature over Peru, 1964-2014. Int. J. Clim. 2017, 38, 283-306. [CrossRef]

44. Juřicová, A.; Fratianni, S. Climate change and its relation to the fluctuation in glacier mass balance in the Cordillera Blanca, Peru: A review. AUC Geogr. 2018, 53, 106-118. [CrossRef]

45. Barr, I.D.; Lynch, C.M.; Mullan, D.; De Siena, L.; Spagnolo, M. Volcanic impacts on modern glaciers: A global synthesis. Earth-Sci. Rev. 2018, 182, 186-203. [CrossRef]

46. Oerlemans, J.; Giesen, R.; Broeke, M.V.D. Retreating alpine glaciers: increased melt rates due to accumulation of dust (Vadret da Morteratsch, Switzerland). J. Glaciol. 2009, 55, 729-736. [CrossRef]

47. Sievers, W. Uber Schneeverhaltnisse in der Cordillere Venezuelas (on snow conditions in the Venezuelan Cordillera). Jahresbericht der Geographischen Gesellschaft in Miinchen 1886, 10, 54-57.

48. Sievers, W. Zur Vergletscherung der Cordilleren des tropischen Siidamerikas (glaciation of the cordillera of tropical South America). Zeitschrift fur Gletscherkunde 1908, 2, 271-284.

49. Sievers, W. Die heutige und die fruhere Vergletscherung Siidamerikas (present-day and past glaciation in South America). F.C.W. Vogel 1911, 1-24.

50. Jahn, A. La cordillera Venezolana de los Andes (The Andean Cordillera of Venezuela). Revista Técnica del Ministerio de Obras Publicas 1912, 1-40.

51. Jahn, A. Mis ascensiones a la Sierra Nevada de Merida (My ascents to the Sierra Nevada de Merida). El Cojo Illustrado 1912, 497, 466-474.

52. Jahn, A. El deshielo de la Sierra Nevada de Merida y sus causas (The deglaciation of the Sierra Nevada de Merida and its causes). Cultura Venezolana 1931, 110, 5-15.

53. Jahn, A. Observaciones glaciologicas en los Andes venezolanos (Glaciological observations in the Venezuelan Andes). Cultura Venezolana 1925, 64, 265-280.

54. Ancizar, M. Peregrinacion de Alpha (M. Ancizar) por las Provincias del Norte de la Nueva Granada, en 1850 i 51 ; Echeverria Hermanos: Bogota, Colombia, 1853; p. 1853.

55. Reiss, W.; Stübel, A. Reisen in Sud-America; Geologische Studien in der Republik Colombia (Expeditions in South America; geological studies in the Republic of Colombia); A. Asher \& Company: Berlin, Germany, 1893; p. 204.

56. Stübel, A.; Wolf, T. Die Vulkanberge von Colombia (The volcanic mountains of Colombia); Wilhelm Baensch: Dresden, Germany, 1996; p. 154.

57. Notestein, F.B.; King, R.E. The Sierra Nevada de Cocuy. Geogr. Rev. 1932, 22, 423. [CrossRef]

58. Coleman, A.P. Pleistocene Glaciation in the Andes of Colombia. Geogr. J. 1935, 86, 330. [CrossRef]

59. Cabot, T.D.; Wood, W.A.; Notestein, F.B. The Cabot Expedition to the Sierra Nevada de Santa Marta of Colombia. Geogr. Rev. 1939, 29, 587. [CrossRef]

60. Wood, W.A. Mapping the Sierra Nevada de Santa Marta: The Work of the Cabot Colombian Expedition. Geogr. Rev. 1941, 31, 639. [CrossRef] 
61. Oppenheim, V. Pleistocene glaciations in Colombia, South America. In Proceedings of the Congreso Panamericano de Ingenieria de Minas y Geologia, 1st Anales, Santiago, Chile; 1942; pp. 834-848.

62. Oppenheim, V.; Spann, H.J. Investigaciones glaciologicas en el Peru 1944-1945; Institute Geologico del Peru: Lima, Peru, 1946.

63. Pritchett, G.J. Explorations in Ecuador in 1856-7. Proc. R. Geogr. Soc. Lond. 1858, 3, 93-98. [CrossRef]

64. Whymper, E. A Journey among the Great Andes of the Equator. Proc. Geogr. Soc. Mon. Geogr. 1881, $3,449$. [CrossRef]

65. Stabler, J.H. Travels in Ecuador. Geogr. J. 1917, 50, 241. [CrossRef]

66. Sinclair, J.H. In the Land of Cinnamon: A Journey in Eastern Ecuador. Geogr. Rev. 1929, 19, 201. [CrossRef]

67. Sinclair, J.H.; Wasson, T. Explorations in Eastern Ecuador. Geogr. Rev. 1923, 13, 190. [CrossRef]

68. Sheppard, G. The Occidente of Ecuador: A Journey from Quito to the Pacific. Geogr. J. 1935, 86, 411. [CrossRef]

69. Raimondi, A. El Departamento de Ancachs y sus Riquezas Minerales; Enrique Meiggs: Lima, Peru, 1873.

70. Kinzl, H. Gegenwartige und eiseitliche Vergletscherung in der Cordillera Blanca (Peru). Verhandlungen des Deutschen Geographentages 1935, 41-56.

71. Kinzl, H. La ruptura del lago glacial en la Quebrada de Ulta en el ano 1938. Javier Prado Boletin 1940, 4, 153-167.

72. Kinzl, H. Gletscherkundliche Begleitworte zur Karte der Cordillera Blanca. Zeitschrift fur Gletscherkunde 1942, 28, 1-19.

73. Kinzl, H. Die Vergletscherung in der Südhälfte der Cordillera Blanca (Peru). Zeitschrift fur Gletscherkunde und Glazialgeologie 1949, 1, 1-28.

74. Kinzl, H.; Schneider, E.; Ebster, E. Die Karte der Kordillere von Huayhuash (Peru). Zeitschrift der Gesellschaft fiir Erdkunde zu Berlin 1942, 1-35.

75. Broggi, J.A. La desglaciacion Andina y sus consecuencias. Revista de Ciencias 1943, 45, 159-173.

76. Broggi, J.A. La desglaciacion actual de los Andes del Peru. "Javier Prado" Boletín 1945, 35, 222-248.

77. Heim, A. Observaciones glaciologicas en la Cordillera Blanca-Peni (Glaciological observations in the Cordillera Blanca-Peru). Sociedad Geologica del Peru Boletin 1947, 20, 119-122.

78. Szepessy, A. Contribución al conocimiento de las lagunas glaciares en la Cordillera Blanca. Sociedad Geologica del Peru Boletin 1949, 25, 5.

79. Szepessy, A. Monografica Preliminar de la Cordillera Blanca; La Corporación Peruana del Santa fue: Lima, Peru, 1950; pp. 2-64.

80. d'Orbigny, A. Voyage dans I'Amerique Meridionale (le Bresil, la Republique orientale de 1'Uruguay, la Republique Argentine, la Patagonie, la Republique du Chili, la Republique de Bolivia, la Republique du Perou), execute pendant les annees 1826, 1827, 1828, 1829, 1830, 1831, 1832 et 1833; Chez Pitois-Levrault et Cie: Paris, France, 1855.

81. Conway, M. Notes on a Map of Part of the Cordillera Real of Bolivia. Geogr. J. 1900, 15, 528. [CrossRef]

82. Hauthal, R.J.F. Reisen in Bolivien und Peru, ausgefuhrt 1908. Duneker and Humbolt 1911, 247.

83. Herzog, T. Vom Urwald zu den Gletschern der Kordillere; 2 Forschungsreisen in Bolivien. Strecker and Schroder 1913, 270.

84. Herzog, T. Beitrage zur Kenntnis von Tektonik und Glazial der bolivischen Ostkordillere. Geologische Rundschau 1915, 5, 353-371. [CrossRef]

85. Troll, C. Büsserschnee (Nieve de los penitentes) in den Hochgebirgen der Erde. Ein Beitrag zur Geographie der Schneedecke und ihrer Ablationsformen; Justus Perthes: Gotha, Germany, 1942; p. 103.

86. Troll, C.; Finsterwalder, R. Die Karten der Cordillera Real und des Talkessels von La Paz and die Diluvialgeschichte der zentralen Anden. Petermanns Geographische Mitteilungen 1935, 81, 393-399, 445-455.

87. Ahlfeld, F. Geologia de Bolivia; Ministerio de Economia Nacional: La Plata, Argentina, 1946; p. 189.

88. Helbling, R. Beiträge Zur Topographischen Erschliessung Der Cordillera De Los Andes Zwischen Aconcagua Und Tupungato; Akademischer Alpenclub Zürich: Zürich, Switzerland, 1919; p. 77.

89. Helbling, R. The Origin of the Rio Plomo Ice-Dam. Geogr. J. 1935, 85, 41. [CrossRef]

90. Krapf, J.L. Von der afrikanischen Ostküste. Zeitschrift der Deutschen Morgenländischen Gesellschaft 1849, 3 , 310-321.

91. Gregory, J.W. Contributions to the geology of British East Africa, part-1, The glacial geology of Mount Kenya. Q. J. Geol. Soc. Lond. 1894, 50, 515-530. [CrossRef] 
92. Gregory, J.W. The Great Rift Valley: Being the Narrative of a Journey to Mount Kenya and Lake Baringo: with Some Account of the Geology, Natural History, Anthropology and Future Prospects of British East Africa; John Murray: London, UK, 1896; p. 422.

93. Mackinder, H.J. A Journey to the Summit of Mount Kenya, British East Africa. Geogr. J. 1900, 15, 453. [CrossRef]

94. Dutton, E.A.T. Kenya Mountain; Jonathan Cape: London, UK, 1929; p. 218.

95. Nilsson, E. Quaternary Glaciations and Pluvial Lakes in British East Africa. Geogr. Ann. 1931, 13, 249. [CrossRef]

96. Rebmann, J. Narrative of a journey to Jagga, the snow country of East Africa. Church Missionary Rev. 1849, 1, 12-23.

97. Johnston, H.H. The Kilimanjaro expedition. In Proceedings of the Royal Geographical Society and Monthly Record of Geography, 23 February 1985; 7, pp. 137-160.

98. Klute, F. Ergebnisse der Forschungen am Kilimandscharo 1912; Dietrich Reimer: Berlin, Germany, $1920 ;$ p. 136.

99. Stuhlmann, F. Mit Emin Pascha ins Herz von Afrika; Dietrich Reimer: Berlin, Germany, 1894; p. 901.

100. Moore, J.E.S. To the Mountains of the Moon, Being An Account of the Modern Aspect of Central Africa, and of Some Little Known Regions Traversed by the Tanganyika Expedition in 1899 and 1900; Hurst and Blackett Ltd.: London, UK, 1901; p. 350.

101. Abruzzi, H.R.H. The snows of the Nile. Being an account of the exploration of the peaks, passes, and glaciers of Ruwenzori. Geogr. J. 1907, 29, 121-147.

102. Meyer, H. Die Besteigung des Kilimandscharo. Petermanns Mitteilungen 1890, 36, 15-22.

103. Meyer, H. Ostafrikanische Gletscherfahrten Forschungsreisen im Kilimandscharo-Geibiet; Duncker and Humblot: Leipzig, Germany, 1890; p. 376.

104. Meyer, H. Across East African Glaciers: An Account of the First Ascent of Kilimanjaro. George Philip and Son: London, UK, 1891; p. 404.

105. Meyer, H. Der Kilimandjaro. Reisen und Studien; Dietrich Reimer: Berlin, Germany, 1900; p. 436.

106. Busk, D. The Southern Glaciers of the Stanley Group of the Ruwenzori. Geogr. J. 1954, 120, 137. [CrossRef]

107. Neill, W.T. Twentieth-Century Indonesia; Columbia University Press: New York, NY, USA, 1973; p. 413.

108. Lorentz, H.A. Zwarte Menschen-Witte Bergen: Verhaal Van Den Tocht Naar Het Sneeuwgebergte Van Nieuw-Guinea; E.J. Brill: Leiden, The Netherlands, 1913.

109. Veettil, B.K.; Kamp, U. Remote sensing of glaciers in the tropical Andes: a review. Int. J. Sens. 2017, 38, 7101-7137. [CrossRef]

110. Sagredo, E.; Lowell, T.; Sagredo, E.; Lowell, T. Climatology of Andean glaciers: A framework to understand glacier response to climate change. Planet. Chang. 2012, 86, 101-109. [CrossRef]

111. Ceballos, J.L.; Euscátegui, C.; Ramírez, J.; Cañon, M.; Huggel, C.; Haeberli, W.; Machguth, H. Fast shrinkage of tropical glaciers in Colombia. Ann. Glaciol. 2006, 43, 194-201. [CrossRef]

112. Cáceres, B. Actualización del Inventario de Tres Casquetes Glaciares del Ecuador. Master's Thesis, University of Nice, Nice, France, 2010.

113. Braun, C.; Bezada, M. The history and disappearance of glaciers in venezuela. J. Lat. Am. Geogr. 2013, 12, 85-124. [CrossRef]

114. Rekowsky, I.C. Variações de Área das Geleiras da Colômbia E da Venezuela Entre 1985 E 2015, Com Dados De Sensoriamento Remoto. Master's Thesis, Federal University of Rio Grande do Sul, Porto Alegre, Brazil, 2016.

115. Morris, J.N.; Poole, A.J.; Klein, A.G. Retreat of tropical glaciers in Colombia and Venezuela from 1984 to 2004 as measured from ASTER and Landsat images. In Proceedings of the 63rd Eastern Snow Conference, Newark, NJ, USA, 7-9 June 2006; pp. 181-191.

116. Jordan, E.; Geyer, K.; Linder, W.; Fernandez, B.; Florez, A.; Mojica, J.; Niño, O.; Torrez, C.; Guarnizo, F. The recent glaciation of the Colombian Andes. Zentralblatt für Geologie und Paläontologie 1989, 1, 1113-1117.

117. Jordan, E.; Ungerechts, L.; Cáceres, B.; Penafiel, A.; Francou, B. Estimation by photogrammetry of the glacier recession on the Cotopaxi Volcano (Ecuador) between 1956 and 1997. Hydrol. Sci. J. 2005, 50, 949-961.

118. Cáceres, B.; Ramirez, J.; Francou, B.; Eissen, J.P.; Taupin, J.D.; Jordan, E.; Ungerechts, L.; Maisincho, L.; Barba, D.; Cadier, E.; et al. Determinación del Volúmen del casquete de hielo del Volcán Cotopaxi; Biblioteca Virtual del Programa Hidrológico Internacional para América Latina y el Caribe de la UNESCO: Quito, Ecuador, 2004.

119. Ames, A.; Hastenrath, S. Recession of Yanamarey Glacier in Cordillera Blanca, Peru, during the 20th century. J. Glaciol. 1995, 41, 191-196. 
120. Georges, C. The 20th century glacier fluctuations in the tropical Cordillera Blanca, Peru. Arct. Antarct. Alp. Res. 2004, 36, 100-107. [CrossRef]

121. Racoviteanu, A.E.; Arnaud, Y.; Williams, M.W.; Ordoñez, J. Decadal changes in glacier parameters in the Cordillera Blanca, Peru, derived from remote sensing. J. Glaciol. 2008, 54, 499-510. [CrossRef]

122. Burns, P.; Nolin, A. Using atmospherically-corrected Landsat imagery to measure glacier area change in the Cordillera Blanca, Peru from 1987 to 2010. Remote. Sens. Environ. 2014, 140, 165-178. [CrossRef]

123. Hanshaw, M.N.; Bookhagen, B. Glacial areas, lake areas, and snow lines from 1975 to 2012: Status of the Cordillera Vilcanota, including the Quelccaya Ice Cap, northern central Andes, Peru. The Cryosphere 2014, 8, 359-376. [CrossRef]

124. Veettil, B.K.; De Souza, S.F.; Simões, J.C.; Pereira, S.F.R. Decadal evolution of glaciers and glacial lakes in the Apolobamba-Carabaya region, tropical Andes (Bolivia-Peru). Geogr. Ann. Ser. A, Phys. Geogr. 2017, 99, 193-206. [CrossRef]

125. Aubry-Wake, C.; Zephir, D.; Naraer, M.; McKenzie, J.M.; Mark, B.G. Importance of longwave emissions from adjacent terrain on patterns of tropical glacier melt and recession. J. Glaciol. 2018, 64, 49-60. [CrossRef]

126. Yarleque, C.; Vuille, M.; Hardy, D.R.; Timm, O.E.; De La Cruz, J.; Ramos, H.; Rabatel, A. Projections of the future disappearance of the Quelccaya Ice Cap in the Central Andes. Sci. Rep. 2018, 8, 15564. [CrossRef]

127. Kochtitzky, W.H.; Edwards, B.R.; Enderlin, E.M.; Mariño, J.; Marinque, N. Improved estimates of glacier change rates at Nevado Coropuna Ice Cap, Peru. J. Glaciol. 2018, 64, 175-184. [CrossRef]

128. Ramirez, E.; Francou, B.; Ribstein, P.; Descloitres, M.; Guérin, R.; Mendoza, J.; Gallaire, R.; Pouyaud, B.; Jordan, E. Small glaciers disappearing in the tropical Andes: A case study in Bolivia-The Chacaltaya glacier, $16^{\circ}$ S. J. Glaciol. 2001, 47, 187-194. [CrossRef]

129. Bicca, C.E. Variações nas geleiras da porção norte da Cordilheira Real durante o período de 1984 a 2010 através do sensoriamento remoto. Master's Thesis, State University of Rio Grande do Sul, Porto Alegre, Brazil, 2012.

130. Kruss, P. Climatic change in East Africa: numerical modelling from the 100 years terminus record of Lewis Glacier, Mount Kenya. Zeitschrift fur Gletscherkunde und Glazialgeologie 1983, 19, 43-60.

131. Hastenrath, S. The Glaciers of Equatorial East Africa; Springer Nature, 1984; p. 353.

132. Kaser, G. A review of the modern fluctuations of tropical glaciers. Planet. Chang. 1999, 22, 93-103. [CrossRef]

133. Chen, A.; Wang, N.; Guo, Z.; Wu, Y.; Wu, H. Glacier variations and rising temperature in the Mt. Kenya since the Last Glacial Maximum. J. Mt. Sci. 2018, 15, 1268-1282. [CrossRef]

134. Hastenrath, S.; Caukwell, R.A. Variations of Lewis Glacier, Mount Kenya, 1974-78. Erdkunde 1979, 33, $292-297$. [CrossRef]

135. Prinz, R.; Fischer, A.; Nicholson, L.; Kaser, G. Seventy-six years of mean mass balance rates derived from recent and re-evaluated ice volume measurements on tropical Lewis Glacier, Mount Kenya. Geophys. Lett. 2011, 38. [CrossRef]

136. Prinz, R.; Heller, A.; Ladner, M.; Nicholson, L.I.; Kaser, G. Mapping the loss of Mt. Kenya's glaciers: An example of the challenges of satellite monitoring of very small glaciers. Geosciences 2018, 8, 174. [CrossRef]

137. Hastenrath, S. Diagnosing the decaying glaciers of equatorial East Africa. Meteorol. Z. 2006, 15, $265-271$. [CrossRef]

138. Hastenrath, S.; Greischar, L. Glacier recession on KiliIl1.anjaro, East Africa, 1912-89. J. Glaciol. 1997, 43, 455-459. [CrossRef]

139. Thompson, L.G.; Mosley-Thompson, E.; Davis, M.E.; Henderson, K.A.; Brecher, H.H.; Zagorodnov, V.S.; Mashiotta, T.A.; Lin, P.-N.; Mikhalenko, V.N.; Hardy, D.R.; et al. Kilimanjaro ice core records: Evidence of Holocene climate change in Tropical Africa. Science 2002, 298, 589-593. [CrossRef]

140. Cullen, N.J.; Mölg, T.; Kaser, G.; Hussein, K.; Steffen, K.; Hardy, D.R. Kilimanjaro Glaciers: Recent areal extent from satellite data and new interpretation of observed 20th century retreat rates. Geophys. Lett. 2006, 33. [CrossRef]

141. Bohleber, P.; Sold, L.; Hardy, D.R.; Schwikowski, M.; Klenk, P.; Fischer, A.; Sirguey, P.; Cullen, N.J.; Potocki, M.; Hoffmann, H.; et al. Ground-penetrating radar reveals ice thickness and undisturbed englacial layers at Kilimanjaro's Northern Ice Field. The Cryosphere 2017, 11, 469-482. [CrossRef]

142. WWF (World Wide Fund for Nature). Climate Change Impacts on East Africa. Review of Scientific Literature. Available online: https://www.wwf.or.jp/activities/lib/pdf_climate/environment/east_africa_climate_change_ impacts_final.pdf (accessed on 7 September 2017). 
143. Unmüßig, B.; Crame, S. Climate change in Africa; GIGA Focus: Hamburg, Germany, 2008.

144. Whittow, J.B.; Temple, P.H.; Shepherd, A.; Goldthorpe, J.E. Observations on the Glaciers of the Ruwenzori. J. Glaciol. 1963, 4, 581-616. [CrossRef]

145. Temple, P.H. Further Observations on the Glaciers of the Ruwenzori. Geogr. Ann. Ser. A, Phys. Geogr. 1968, 50, 136. [CrossRef]

146. Noggler, B.; Kaser, G. Observations on Speke Glacier, Ruwenzori Range, Uganda. J. Glaciol. 1991, 37, 313-318.

147. Taylor, R.G.; Mileham, L.; Tindimugaya, C.; Majugu, A.; Muwanga, A.; Nakileza, B. Recent glacial recession in the Rwenzori Mountains of East Africa due to rising air temperature. Geophys. Lett. 2006, 33. [CrossRef]

148. Barnett, T.P.; Adam, J.C.; Lettenmaier, D.P. Potential impacts of a warming climate on water availability in snow-dominated regions. Nat. Cell Boil. 2005, 438, 303-309. [CrossRef]

149. Taylor, R.G.; Mileham, L.; Tindimugaya, C.; Mwebembezi, L. Recent glacial recession and its impact on alpine riverflow in the Rwenzori Mountains of Uganda. J. Afr. Earth Sci. 2009, 55, 205-213. [CrossRef]

150. Huss, M.; Bookhagen, B.; Huggel, C.; Jacobsen, D.; Bradley, R.; Clague, J.; Vuille, M.; Buytaert, W.; Cayan, D.; Greenwood, G.; et al. Toward mountains without permanent snow and ice. Earth's Futur. 2017, 5, 418-435. [CrossRef]

151. Vuille, M. Climate Change and Water Resources in the Tropical Andes; Inter-American Development Bank Technical Note No. IDB-TN-515; Inter-American Development Bank: Washington, DC, USA, 2013.

152. Mark, B.G.; McKenzie, J.M. Tracing Increasing Tropical Andean Glacier Melt with Stable Isotopes in Water. Environ. Sci. Technol. 2007, 41, 6955-6960. [CrossRef]

153. Bury, J.T.; Mark, B.G.; Mckenzie, J.M.; French, A.; Baraer, M.; Huh, K.I.; Zapata, M.A.; Gomez, R.J. Glacier recession and human vulnerability in the Yanamarey watershed of the Cordillera Blanca, Peru. Clim. Change 2011, 105, 179-206. [CrossRef]

154. IDEAM. Glaciares De Colombia - Más Que Montañas Con Hielo; Instituto de Hidrologia, meteorología y Estudios Ambientales: Bogotá, Colombia, 2012; p. 346.

155. Harden, C.P. Human impacts on headwater fluvial systems in the northern and central Andes. Geomorphology 2006, 79, 249-263. [CrossRef]

156. Juen, I.; Kaser, G.; Georges, C. Modelling observed and future runoff from a glacierized tropical catchment (Cordillera Blanca, Perú). Planet. Chang. 2007, 59, 37-48. [CrossRef]

157. Baraer, M.; Mark, B.G.; McKenzie, J.M.; Condom, T.; Bury, J.; Huh, K.-I.; Portocarrero, C.; Gómez, J.; Rathay, S. Glacier recession and water resources in Peru's Cordillera Blanca. J. Glaciol. 2012, 58, 134-150. [CrossRef]

158. Baraer, M.; McKenzie, J.; Mark, B.G.; Gordon, R.; Bury, J.; Condom, T.; Gomez, J.; Knox, S.; Fortner, S.K. Contribution of groundwater to the outflow from ungauged glaciarized catchments: a multi-site study in the tropical Cordillera Blanca, Peru. Hydrol. Process 2015, 29, 2561-2581. [CrossRef]

159. Somers, L.D.; Gordon, R.P.; McKenzie, J.M.; Lautz, L.K.; Wigmore, O.; Glose, A.M.; Glas, R.; Aubry-Wake, C.; Mark, B.; Baraer, M.; et al. Quantifying groundwater-surface water interactions in a proglacial valley, Cordillera Blanca, Peru. Hydrol. Process. 2016, 30, 2915-2929. [CrossRef]

160. Coudrain, A.; Francou, B.; Kundzewicz, Z.W. Glacier shrinkage in the Andes and consequences for water resources. Hydrol. Sci. J. 2005, 50, 925-932.

161. Soruco, A.; Vincent, C.; Rabatel, A.; Francou, B.; Thibert, E.; Sicart, J.E.; Condom, T. Contribution of glacier runoff to water resources of La Paz city, Bolivia (16 S). Ann. Glaciol. 2015, 56, 147-154. [CrossRef]

162. Vergara, W.; Deeb, A.; Valencia, A.; Bradley, R.; Francou, B.; Zarzar, A.; Grunwaldt, A.; Haeussling, S. Economic impacts of rapid glacier retreat in the Andes. Eos Trans. AGU 2007, 88, 261-264. [CrossRef]

163. Rangecroft, S.; Harrison, S.; Anderson, K.; Magrath, J.; Castel, A.P.; Pacheco, P. Climate Change and Water Resources in Arid Mountains: An Example from the Bolivian Andes. AMBIO 2013, 42, 852-863. [CrossRef]

164. Palmer, J. The Dangers of Glacial Lake Floods: Pioneering and Capitulation. Available online: https://eos.org/ features/the-dangers-of-glacial-lake-floods-pioneering-and-capitulation (accessed on 15 December 2018).

165. Chevallier, P.; Pouyaud, B.; Suarez, W.; Condom, T. Climate change threats to environment in the tropical Andes: glaciers and water resources. Reg. Environ. Change 2011, 11, 179-187. [CrossRef]

166. Vilímek, V.; Zapata, M.L.; Klimeš, J.; Patzelt, Z.; Santillán, N. Influence of glacial retreat on natural hazards of the Palcacocha Lake area, Peru. Landslides 2005, 2, 107-115. [CrossRef]

167. Haeberli, W.; Schaub, Y.; Huggel, C. Increasing risks related to landslides from degrading permafrost into new lakes in de-glaciating mountain ranges. Geomorphology 2017, 293, 405-417. [CrossRef] 
168. Huggel, C.; Clague, J.J.; Korup, O. Is climate change responsible for changing landslide activity in high mountains? Earth Surf. Process. Landf. 2012, 37, 77-91. [CrossRef]

169. Vilímek, V.; Klimeš, J.; Emmer, A.; Benešová, M. Geomorphologic impacts of the glacial lake outburst flood from Lake No. 513 (Peru). Environ. Earth Sci. 2015, 73, 5233-5244. [CrossRef]

170. Carey, M.; Huggel, C.; Bury, J.; Portocarrero, C.; Haeberli, W. An integrated socio-environmental framework for glacier hazard management and climate change adaptation: Lessons from Lake 513, Cordillera Blanca, Peru. Clim. Change 2012, 112, 733-767. [CrossRef]

171. Anderson, E.P.; Marengo, J.; Villalba, R.; Halloy, S.; Young, B.; Cordero, D.; Gast, F.; Jaimes, E.; Ruiz, D. Consequences of climate change for ecosystems and ecosystem services in the tropical Andes. In Climate Change and Biodiversity in the Tropical Andes; Herzog, S.K., Martínez, R., Eds.; Inter-American Institute for Global Change Research: São José dos Campos, Brazil, 2011.

172. Buytaert, W.; Célleri, R.; De Bièvre, B.; Cisneros, F.; Wyseure, G.; Deckers, J.; Hofstede, R. Human impact on the hydrology of the Andean páramos. Earth-Sci. Rev. 2006, 79, 53-72. [CrossRef]

173. Buytaert, W.; Cuesta-Camacho, F.; Tobon, C. Potential impacts of climate change on the environmental services of humid tropical alpine regions. Glob. Ecol. Biogeogr. 2011, 20, 19-33. [CrossRef]

174. Buytaert, W.; De Bièvre, B. Water for cities: The impact of climate change and demographic growth in the tropical Andes. N.a. Resour. 2012, 48, 08503. [CrossRef]

175. Villacis, M. Ressources En Eau Glaciaire Dans Les Andes D'equateur En Relation Avec Les Variations Du Climat: Le Cas Du Volcan Antisana. Ph.D. Thesis, Université Montpellier II, Montpellier, France, 2008.

176. Rhoades, R. A vanishing Andean glacier: History, local perceptions, and societal impacts of climate change in Cotacachi, Ecuador. In Proceedings of the conference on Global Change in Mountain Regions, Perth, UK, 2-6 October 2005.

177. Polk, M.H.; Young, K.R.; Baraer, M.; Mark, B.G.; McKenzie, J.M.; Bury, J.; Carey, M. Exploring hydrologic connections between tropical mountain wetlands and glacier recession in Peru's Cordillera Blanca. Appl. Geogr. 2017, 78, 94-103. [CrossRef]

178. Dangles, O.; Rabatel, A.; Kraemer, M.; Zeballos, G.; Soruco, A.; Jacobsen, D.; Anthelme, F. Ecosystem sentinels for climate change? Evidence of wetland cover changes over the last 30 years in the tropical Andes. PLoS ONE 2017, 12, e0175814. [CrossRef] [PubMed]

179. Seimon, T.A.; Seimon, A.; Daszak, P.; Halloy, S.R.; Schloegel, L.M.; Aguilar, C.A.; Sowell, P.; Hyatt, A.D.; Konecky, B.; E Simmons, J. Upward range extension of Andean anurans and chytridiomycosis to extreme elevations in response to tropical deglaciation. Chang. Boil. 2007, 13, 288-299. [CrossRef]

180. Zimmer, A.; Meneses, R.I.; Rabatel, A.; Soruco, A.; Dangles, O.; Anthelme, F.; Zimmer, A. Time lag between glacial retreat and upward migration alters tropical alpine communities. Perspect. N.a. Ecol. Evol. Syst. 2018, 30, 89-102. [CrossRef]

181. Young, K.R.; Ponette-Gonzalez, A.G.; Polk, M.H.; Lipton, J.K. Snowlines and treelines in the Tropical Andes. Ann. Am. Assoc. Geogr. 2017, 107, 429-440. [CrossRef]

182. Young, K.R. Ecology of land cover change in glaciated tropical mountains. Revista Peruana de Biologia 2014, 21, 259-270.

183. Hardy, S.P.; Hardy, D.R.; Gil, K.C. Avian nesting and roosting on glaciers at high elevation, Cordillera Vilcanota, Peru. Wilson J. Ornithol. 2018, 130, 940-958. [CrossRef]

184. Sophie, C.F.; Patricio, A.; Rodrigo, A.; Roger, C.; Fabien, A.; Dean, J.; Olivier, D. Glacial flood pulse effects on benthic fauna in equatorial high-Andean streams. Hydrol. Process. 2013, 28, 3008-3017.

185. Van Colen, W.; Portilla, K.; Oña, T.; Wyseure, G.; Goethals, P.; Velarde, E.; Muylaert, K. Limnology of the neotropical high elevation shallow lake Yahuarcocha (Ecuador) and challenges for managing eutrophication using biomanipulation. Limnol. Ecol. Manag. Inland Waters 2017, 67, 37-44. [CrossRef]

186. Michelutti, N.; Wolfe, A.P.; Cooke, C.A.; Hobbs, W.O.; Vuille, M.; Smol, J.P. Climate change forces new ecological states in tropical andean lakes. PloS One 2015, 10, e0115338. [CrossRef]

187. Epstein, P.R.; Diaz, H.F.; Elias, S.; Grabherr, G.; Graham, N.E.; Martens, W.J.M.; Mosley-Thompson, E.; Susskind, J. Biological and Physical Signs of Climate Change: Focus on Mosquito-borne Diseases. Am. Meteorol. Soc. 1998, 79, 409-417. [CrossRef]

188. Poveda, G.; Rojas, W.; Quinones, M.L.; Velez, I.D.; Mantilla, R.I.; Ruiz, D.; Zuluaga, J.S.; Rua, G.L. Coupling between annual and ENSO timescales in the malaria-climate association in Colombia. Environ. Heal. Perspect. 2001, 109, 489-493. 
189. Martin, B. Peru: Zika Virus. Available online: http://digitalcommons.augustana.edu/pubh100global/11 (accessed on 25 March 2018).

190. Rhoades, R.; Zapata, X.; Arangundy, J. Climate change in Cotacachi. In Development With Identity: Community, Culture and Sustainability in the Andes; Rhoades, R., Ed.; CAB eBooks: UK, 2006; p. 64.

191. Instituto Nacional de Estadística e Informática. The 2007 National Census: XI of Population and VI of Houses; Institute of National Statistics and Information: Lima, Peru, 2007.

192. Mark, B.G.; Bury, J.; McKenzie, J.M.; French, A.; Baraer, M. Climate Change and Tropical Andean Glacier Recession: Evaluating Hydrologic Changes and Livelihood Vulnerability in the Cordillera Blanca, Peru. Ann. Assoc. Am. Geogr. 2010, 100, 794-805. [CrossRef]

193. Brown, K.W. Workers' Health and Colonial Mercury Mining at Huancavelica, Peru. The Americas 2001, 57, 467-496. [CrossRef]

194. Guittard, A.; Baraer, M.; McKenzie, J.M.; Mark, B.G.; Wigmore, O.; Fernandez, A.; Rapre, A.C.; Walsh, E.; Bury, J.; Carey, M.; et al. Trace-metal contamination in the glacierized Rio Santa watershed, Peru. Environ. Monit. Assess. 2017, 189, 649. [CrossRef]

195. Célleri, R.; Feyen, J. The Hydrology of Tropical Andean Ecosystems: Importance, Knowledge Status, and Perspectives. Mt. Res. Dev. 2009, 29, 350-355. [CrossRef]

196. Liniger, H.; Weingarten, R.; Grosjean, M. Mountains of the World: Water Towers for the 21st Century. Mountain Agenda, Center for Development and Environment; University of Bern: Bern, The Switzerland, 1998; pp. 1-24.

197. Soruco, A.; Vincent, C.; Francou, B.; Ribstein, P.; Berger, T.; Sicart, J.; Wagnon, P.; Arnaud, Y.; Favier, V.; Lejeune, Y. Mass balance of Glaciar Zongo, Bolivia, between 1956 and 2006, using glaciological, hydrological and geodetic methods. Ann. Glaciol. 2009, 50,1-8. [CrossRef]

198. Kaenzig, R.; Rebetez, M.; Serquet, G. Climate change adaptation of the tourism sector in the Bolivian Andes. Tour. Geogr. 2016, 18, 1-18. [CrossRef]

199. Wright, S.K. Melting Marvels: Tourist Responses to Climate Change and Glacial Melt in the Peruvian Andes. MSc Thesis, Ohio State University, Columbus, OH, USA, 2009.

200. Byers, A.C. Contemporary Landscape Change in the Huascarán National Park and Buffer Zone, Cordillera Blanca, Peru. Mt. Res. Dev. 2000, 20, 52-63. [CrossRef]

201. The Circulation of People - A Critical Discussion on the Impact of Glacier Shrinkage Upon Population Mobility in the Bolivian Andes. Available online: https://www2.unine.ch/files/content/sites/maps/files/shared/ documents/wp/WP7_Kae_2013.pdf (accessed on 18 January 2019).

202. Barros, A.; Monz, C.; Pickering, C. Is tourism damaging ecosystems in the Andes? Current knowledge and an agenda for future research. Ambio 2015, 44, 82-98. [PubMed]

203. Casado, M.A. Case method application in tourism education: Bolivia's sustainable tourism plan? Int. J. Case Method Res. Appl. 2005, 17, 1-7.

204. Pilgrims Crowd Peru's Snow Star Festival Fearing for A Sacred Glacier. Available online: https://www.smh. com.au/world/pilgrims-crowd-perus-snow-star-festival-fearing-for-a-sacred-glacier-20160604-gpbjcz.html (accessed on 29 August 2018).

205. Ceruti, C. Sacred ice melting away: lessons from the impact of climate change on Andean cultural heritage. J. Sustain. Educ. 2013, 4, 1-9.

206. Bebbington, A.; Williams, M. Water and mining conflicts in Peru. Mt. Res. Dev. 2008, 28, 190-195. [CrossRef]

207. Carey, M.; French, A.; O'Brien, E. Unintended effects of technology on climate change adaptation: an historical analysis of water conflicts below Andean Glaciers. J. Hist. Geogr. 2012, 38, 181-191. [CrossRef]

208. Warn, E.; Adamo, S.B. The impact of climate change: Migration and cities in South America. Bull. World Meteorol. Organ. 2014, 63. Available online: https://public.wmo.int/en/resources/bulletin/impact-of-climatechange-migration-and-cities-south-america (accessed on 18 January 2019).

209. World Bank. Turn Down the Heat: Confronting the New Climate Normal; World Bank Group: Washington, DC, USA, 2014.

210. Tacoli, C. Crisis or adaptation? Migration and climate change in a context of high mobility. Environ. Urban. 2009, 21, 513-525. [CrossRef]

211. World Bank. Turn Down the Heat: Climate Extremes, Regional Impacts, and the Case for Resilience. A report for the World Bank by the Potsdam Institute for Climate Impact Research and Climate Analytics; World Bank Group: Washington, DC, USA, 2013. 
212. Bolin, I. The glaciers of the Andes are melting: indigenous and anthropological knowledge merge in restoring water resources. In Anthropology and Climate Change: From Encounters to Actions; Crate, S.A., Nuttall, M., Eds.; Left Coast Press: Walnut Creek, CA, USA, 2009; pp. 228-239.

213. Sebastien, L. Quand le climat invite à réintégrer le "non-humain" dans le champ de l'action publique. Le cas des Chagga sur les pentes du Kilimandjaro, Tanzanie. In Le Changement Climatique. Quand le Climat Nous Pousse à Changer D'ère; Scarwell, H.-J., Roussel, I., Eds.; Universitaires du Septentrion: Villeneuve d'Ascq, France, 2010; pp. 65-120.

214. Gagné, K.; Rasmussen, M.B.; Orlove, B. Glaciers and society: attributions, perceptions, and valuations. Wiley Interdiscip. Rev. Clim. Chang. 2014, 5, 793-808. [CrossRef]

215. MWE. Uganda Water and Environment Sector Performance Report 2011; Ministry of Water, Lands and Environment: Kampala, Uganda, 2011.

216. Mizuno, K. Vegetation succession in relation to glacial fluctuation in the high mountains of Africa. Mt. Res. Dev. 2005, 25, 68-75. [CrossRef]

217. Zawierucha, K.; Gasiorek, P.; Buda, J.; Uetake, J.; Janko, K.; Fontaneto, D. Tardigrada and Rotifera from moss microhabitats on a disappearing Ugandan glacier, with the description of a new species of water bear. Zootaxa 2018, 4392, 311-328. [CrossRef] [PubMed]

218. Epstein, P.R. Climate change and emerging infectious diseases. Microbes Infect. 2001, 3, 747-754. [CrossRef]

219. Adhikari, U.; Nejadhashemi, A.P.; Woznicki, S.A. Climate change and eastern Africa: a review of impact on major crops. Food Energy Secur. 2015, 4, 110-132. [CrossRef]

220. Mulangu, F.; Kraybill, D. Climate change and the future of mountain farming on Mt. Kilimanjaro. In The Future of Mountain Agriculture; Mann, S., Ed.; Springer: Berlin/Heidelberg, Germany; pp. 73-88.

221. Mitchell, J.; Keane, J.; Laidlaw, J. Making Success Work for the Poor: Package Tourism in Northern Tanzania. Final Report; Overseas Development Institute: London, UK, 2009; p. 14.

222. GWP. Integrated Water Resources Managemen; Global Water Partnership (GWP): Stockholm, Sweden, 2000.

223. Thompson, L.G.; Mosley-Thompson, E.; Davis, M.E.; Brecher, H.H. Tropical glaciers, recorders and indicators of climate change, are disappearing globally. Ann. Glaciol. 2011, 52, 23-34. [CrossRef]

224. Mark, B.G.; Fernández, A. The significance of mountain glaciers as sentinels of climate and environmental change. Geogr. N.a. 2017, 11,1-16. [CrossRef]

225. Veettil, B.K.; Wang, S.; Simões, J.C.; Pereira, S.F.R.; De Souza, S.F. Regional climate forcing and topographic influence on glacier shrinkage: eastern cordilleras of Peru. Int. J. Clim. 2017, 38, 979-995. [CrossRef]

226. Solomon, S.; Qin, D.; Manning, M.; Marquis, M.; Averyt, K.; Tignor, M.M.B.; Miller, H.L., Jr.; Chen, Z.L. Climate Change 2007: The Physical Science Basis. Contribution of Working Group I to the Fourth Assessment Report of the Intergovernmental Panel on Climate Change; Cambridge University Press: Cambridge, UK, 2007.

227. Chen, Y.; Zhai, P. Persisting and strong warming hiatus over eastern China during the past two decades. Environ. Lett. 2017, 12, 104010. [CrossRef]

228. Emmer, A.; Vilímek, V. Review Article: Lake and breach hazard assessment for moraine-dammed lakes: an example from the Cordillera Blanca (Peru). Hazards Earth Sci. 2013, 13, 1551-1565. [CrossRef]

229. Emmer, A.; Vilímek, V. New method for assessing the susceptibility of glacial lakes to outburst floods in the Cordillera Blanca, Peru. Hydrol. Earth Sci. 2014, 18, 3461-3479. [CrossRef]

230. World Bank Group. Bolivia, Ecuador, and Peru - Adaptation to the Impact of Rapid Glacier Retreat in the Tropical Andes Project; World Bank: Washington, DC, USA, 2014.

231. Buytaert, W.; Beven, K. Models as multiple working hypotheses: Hydrological simulation of tropical alpine wetlands. Hydrol. Processes 2011, 25, 1784-1799. [CrossRef]

232. Reynard, E.; Panizza, M. Geomorphosites: definition, assessment and mapping. An introduction. Géomorphologie: relief, processus, environnement 2005, 11, 177-180. [CrossRef]

(C) 2019 by the authors. Licensee MDPI, Basel, Switzerland. This article is an open access article distributed under the terms and conditions of the Creative Commons Attribution (CC BY) license (http://creativecommons.org/licenses/by/4.0/). 